University of Rhode Island

DigitalCommons@URI

Open Access Master's Theses

2017

\title{
Assessment of Salt Marsh Shoreline Degradation and Restoration on Benthic Invertebrate Infaunal Community
}

Anna Gerber-Williams

University of Rhode Island, anna.gerberwilliams@yahoo.com

Follow this and additional works at: https://digitalcommons.uri.edu/theses

\section{Recommended Citation}

Gerber-Williams, Anna, "Assessment of Salt Marsh Shoreline Degradation and Restoration on Benthic Invertebrate Infaunal Community" (2017). Open Access Master's Theses. Paper 1035.

https://digitalcommons.uri.edu/theses/1035

This Thesis is brought to you for free and open access by DigitalCommons@URI. It has been accepted for inclusion in Open Access Master's Theses by an authorized administrator of DigitalCommons@URI. For more information, please contact digitalcommons-group@uri.edu. 


\author{
ASSESSMENT OF SALT MARSH SHORELINE \\ DEGRADATION AND RESTORATION ON BENTHIC \\ INVERTEBRATE INFAUNAL COMMUNITY \\ COMPOSITION \\ BY
}

ANNA GERBER-WILLIAMS

A THESIS SUBMITTED IN PARTIAL FULFILLMENT OF THE

REQUIREMENTS FOR THE DEGREE OF

MASTER OF SCIENCE IN BIOLOGICAL AND ENVIRONMENTAL SCIENCES

UNIVERSITY OF RHODE ISLAND 


\section{MASTER OF SCIENCE IN BIOLOGICAL AND ENVIRONMENTAL SCIENCES \\ $\mathrm{OF}$ \\ ANNA GERBER-WILLIAMS}

APPROVED:

Thesis Committee:

$\begin{array}{cc}\text { Major Professor } \quad & \text { Laura A. Meyerson } \\ & \text { Suzanne Ayvazian } \\ & \text { Graham Forrester } \\ & \text { Charles Roman } \\ & \text { Nasser H. Zawia } \\ \text { DEAN OF THE GRADUATE SCHOOL }\end{array}$

UNIVERSITY OF RHODE ISLAND

2017 


\begin{abstract}
The benthic invertebrate infaunal community is sensitive to disturbance and is an indicator for the overall health of estuarine ecosystems. To quantify the effect of salt marsh shoreline stabilization and restoration approaches on adjacent habitat quality, we compared invertebrate community assemblages of benthic infauna between four different shoreline types, two of which were erosion control methods, hardened and living shoreline, and two unaltered shorelines, natural and eroded. We quantified benthic infauna density, biomass, richness, and diversity and evaluated physicalchemical factors (water quality, sediment carbon and nitrogen content, and grain size) that may be influencing the benthic invertebrate community associated with the various shoreline treatments.
\end{abstract}

There were significant differences, determined using a one-way ANOVA, $(\mathrm{p}<$ 0.05) in benthic infauna density, diversity and richness between shoreline types over all the seasons. Hardened and eroded shorelines had more variability around the mean density, diversity and species richness across all seasons than the living and natural shorelines suggesting that while living and natural shorelines had lower mean overall abundance they provide a more stable habitat for benthic infauna. Natural and living shorelines had constant predation pressure due to the more complex habitat structure that attracted a larger nekton community than eroded and hardened shoreline treatments. This caused a significant reduction in mean abundance of benthic infauna from May to October of 2015 at all treatment sites but an overall lower mean density and biomass at the natural and living shorelines. Benthic infauna community indices (density, biomass, richness, diversity, and functional groups) differ among shoreline 
treatment sites reflecting ecosystem complexity that is likely driven by resource availability and predation. The hardened and eroded shorelines provided habitat to a more generalist array of organisms in comparison to the more specialized feeding guilds found at the natural and living shorelines, indicating that for restoration purposes a hardened shoreline does not provide a stable state of species assemblages, with more fluctuations in benthic community indices compared with those found at the natural and living shorelines. The findings from this project suggest that the use of living shoreline restoration methods promote habitat complexity similar to that of the natural shoreline resulting in similar trends in species density, richness and diversity. Because benthic infauna are a critical component of the nearshore coastal food web along with increasing societal pressure to protect coastal shorelines from erosion, it is important to consider how restoration methods affect benthic infauna. 


\section{ACKNOWLEDGMENTS}

I would like to thank my graduate advisor Dr. Laura Meyerson for her constant support and guidance during my research project and the writing of this manuscript. I would also like to thank my graduate committee members, Dr. Suzanne Ayvazian, Dr. Graham Forrester, and Dr. Charles Roman, for their time spent reviewing and providing guidance on my research project and writing. This project would not have been possible without my sources of funding from U.S. Fish and Wildlife Services, The Nature Conservancy, and the University of Rhode Island Coastal Institute. Furthermore, I would like to thank Sara Wiggington, Joseph Loffredo, Troy Langknecht, Melissa Burger, Nick Letarte, Rachel Warner, David Cummings and Dawn Perry for their assistance with field collections and laboratory sample processing. For assistance with statistical analysis I would like to thank Dr. Jeffrey Hollister and Dr. Gavino Puggioni. 


\section{PREFACE}

This thesis is written in Manuscript Format for one paper 


\section{TABLE OF CONTENTS}

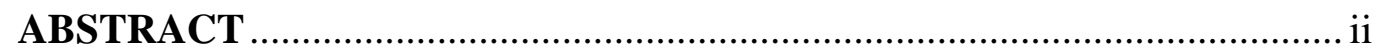

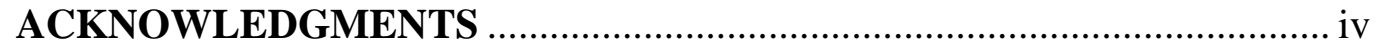

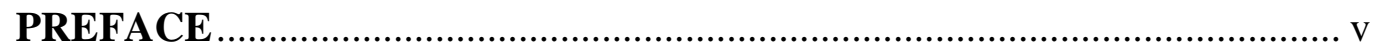

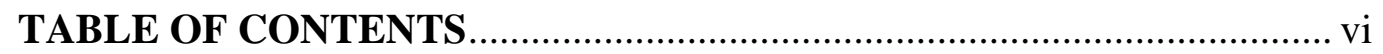

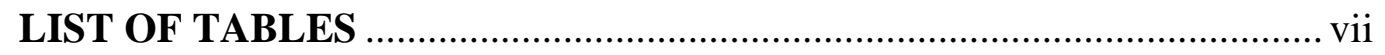

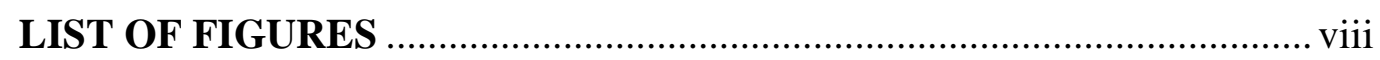

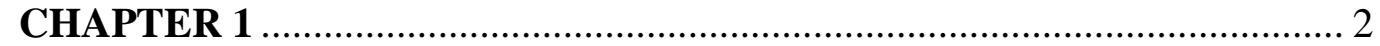

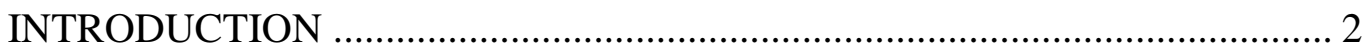

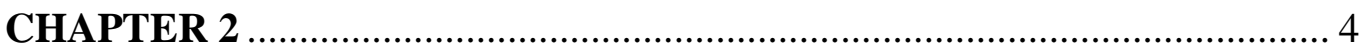

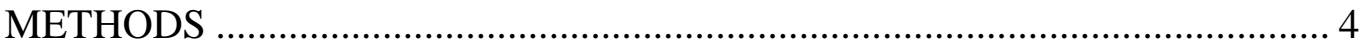

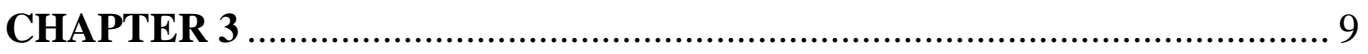

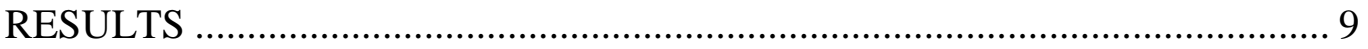

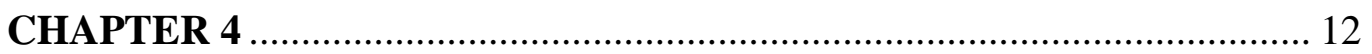

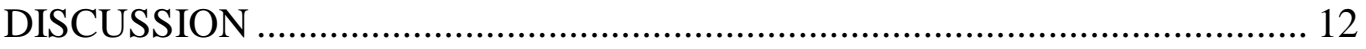

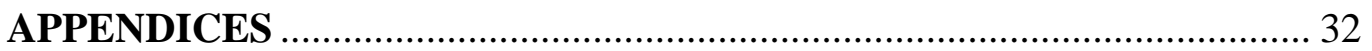

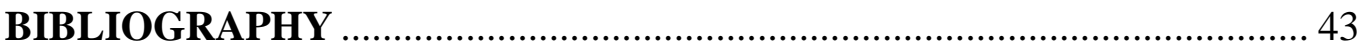




\section{LIST OF TABLES}

TABLE

PAGE

Table 1. Means $( \pm$ SD) of chemical and physical measurements analyzed with a twoway ANOVA by treatment within and between sampling months. A Tukey Multiple comparisons of means was performed to determine significance between treatments.

Sediment data were averaged by core for analysis. Variables with similar superscripts are not significantly different among treatments. Attributes assessed and the metric and method used to analyze the different features.............................. 20

Table 2. Mean abundance, biomass, richness, and Shannon-Wiener diversity (H') ( \pm SD) of all species collected at each treatment in the Narrow River, RI 2015 by date. 


\section{LIST OF FIGURES}

FIGURE

PAGE

Figure 1. Site treatment types and their locations within the Narrow River, Rhode

Island.

22

Figure 2. Transect and core sample collection design applied at each of the shoreline

treatments. Replicate transects are labeled as A and B 23

Figure 3. Mean sediment percent carbon $( \pm$ SD) for each treatment at each sampling period during $2015(\mathrm{df}=56)$. ptreatment*may $<0.05$, $\mathrm{p}_{\text {treatment*aug }}<0.05$, and $\mathrm{p}_{\text {treatment*oct }}=$

0.46 24

Figure 4. Mean sediment percent nitrogen $( \pm$ SD) for each treatment at each sampling period during $2015(\mathrm{df}=56)$. $\mathrm{p}_{\text {treatment }}{ }_{\text {may }}=0.34, \mathrm{p}_{\text {treatment*aug }}<0.05$, and $\mathrm{p}_{\text {treatment*oct }}<$

0.05 . 25

Figure 5. Mean species richness $( \pm \mathrm{SD})$ at each treatment at each sampling period during 2015. The eroded and hardened shoreline have significant differences in richness over the sampling period, $\mathrm{p}_{\mathrm{es} * \mathrm{date}}<0.05$ and $\mathrm{p}_{\mathrm{hs} * \mathrm{date}}<0.05$. 26

Figure 6. Mean infauna density (individuals $\left./ \mathrm{m}^{2}\right)( \pm \mathrm{SD})$ at each treatment at each sampling period during 2015. P-value for density between treatments is significant ( $\mathrm{p}$ $<0.05, \mathrm{df}=3)(\log +1$ transformed $)$

Figure 7. Mean Shannon-Wiener diversity values $( \pm$ SD) at each treatment at each sampling period during 2015. P-value for Shannon-Weiner diversity between the treatments is significant $(\mathrm{p}<0.05, \mathrm{df}=3)$ 
Figure 8. Mean biomass $( \pm \mathrm{SD})$ at each treatment at each sampling period during 2015 .29

Figure 9. The distribution of dominant infauna at each treatment from the three sampling periods during 2015 in the Narrow River, RI. 30 Figure 10. Species functional group distribution at each treatment for May, August, and October 2015. Filter feeder (FF), deposit feeder (DF), scavenger (SC), omnivore (OMNI), carnivore (Carn), herbivore (HERB). 


\section{Manuscript 1}

To be submitted to Marine Progress Series for review Assessment of salt marsh shoreline degradation and restoration on nearshore benthic invertebrate infaunal community composition

Anna M. Gerber-Williams and Laura A. Meyerson

The University of Rhode Island, 1 Greenhouse Road, Kingston, Rhode Island 02881

e-mail: anna.gerberwilliams@yahoo.com 


\section{Introduction}

Rising rates of shoreline loss and change from coastal storms and human activity is increasing global demand to protect important coastal ecosystems and infrastructure (Barbier et al., 2013; Gittman et al., 2016; Lawless \& Seitz, 2014). Landowners in sheltered coastal areas mostly turn to shoreline hardening structures (e.g., sea walls and rock rip rap) to stop erosion, and protect upland infrastructure. However, shoreline hardening removes natural coastal habitat, which is cause for concern because an estimated $22,842 \mathrm{~km}(14 \%)$ of the total US coastal shoreline is currently armored, and of that, $886 \mathrm{~km} \mathrm{(1 \% )} \mathrm{is} \mathrm{fronting} \mathrm{tidal} \mathrm{marsh} \mathrm{(Lawless} \mathrm{\&} \mathrm{Seitz,} \mathrm{2014;}$ Gittman et al., 2015). Unlike natural shorelines, hardened shorelines do not absorb wave energy (O'Connell, 2010) and disrupt natural sediment transport processes (Nordstrom et al., 2009), thus they may negatively impact the surrounding ecosystem. They also decrease nearshore vegetation and physically complex habitat as compared to natural shorelines, potentially causing an adverse impact on fish and invertebrate species that are vital to the estuarine food web (Gittman et al., 2015; Gittman et al., 2016; Lawless \& Seitz, 2014).

Alternatively, hybrid shoreline stabilization methods, referred to as "living shorelines," use a mix of hard structure, such as oyster shell pilings, and natural organic materials such as coconut fiber coir logs, that do not sever the connection between the aquatic and terrestrial environment (RAE, 2015; Sutton-Grier et al., 2015; Swann, 2008). Living shorelines also serve to enhance habitat structure for nekton and benthic invertebrates by adding more complexity to the nearshore zone (Currin et al., 2010; PDE, 2013; Lawless \& Seitz, 2014; Gittman, 2016). The “softer” design 
absorbs more wave energy than hardened shorelines, which slows nearshore water momentum and increases organic and inorganic sediment deposition. Vegetation regrowth is enhanced in the protected shoreline (Craft and Sacco, 2003), restoring belowground biomass and enhancing marsh bank stabilization (Bilkovic \& Roggero, 2008). These benefits from living shoreline restoration have been shown to increase nekton abundance but there is a need for more information on their impacts to benthic infauna productivity (Craft and Sacco, 2003; Gittman et al., 2016; Yepsen et al., 2016; Lawless \& Seitz 2014; Mitchell, 2013)

Benthic invertebrates are commonly used as indicators of ecosystem response to perturbations or to restoration practices because they have a primarily sedentary life cycle and rapidly respond to disturbance or environmental change (Bilkovic \& Havens, 2006; Craft and Sacco, 2003; Nördstrom et al., 2014; Patricio et al., 2009). Little published research exists on the response of benthic infauna to coastal shoreline armoring techniques even though these data are critical for determining the effectiveness of shoreline stabilization restoration practices (Currin, 2010; Savage et al., 2012). Assessments of the extent to which different shoreline protection methods reduce erosion while minimizing impact on the benthic infaunal community are needed to maximize biodiversity and maintain natural food web support functions (Currin et al. 2010). It is also important to understand how the benthic infauna community indices change initially post-installment to truly capture the recolonization over an extended period of time (Seitz et al., 2006; Nordstrom et al., 2014). Due to funding constraints this project only sampled the first year post-installment to determine the baseline benthic infauna succession. 
On the Narrow River, Narragansett RI, we compared armored shorelines (hardened and living shoreline), and two categories of natural shoreline, eroded shoreline (highly eroded) and natural shoreline (minimally eroded) to examine whether shoreline type influenced the adjacent nearshore benthic infaunal community composition and abundance. In addition to community-wide change, we were particularly interested in the feeding guild structure of the benthic infauna species, (such as filter feeders, carnivores, and deposit feeders) which are of particular importance to the estuarine food web (Lawless \& Seitz, 2014).

\section{Materials and Methods}

\section{Study Design and Site Selection}

Four shoreline types were compared: "Eroded Shoreline" (ES), "Hardened Shoreline" (HS), "Living Shoreline" (LS), and "Natural Shoreline” (NS). Shorelines of each type were identified along the Narrow River study area (Figure 1). The Narrow River is a tidal inlet and estuary system connected by a narrow channel to a series of tidal kettle ponds at the northern end. The river spans over $9.5 \mathrm{~km}$ in length with substantial variations in depth (intertidal to 2 meters in the southern part of the river), current velocity (almost zero to $1 \mathrm{~m} / \mathrm{s}$ in narrower sections) and salinity (0-32 ppt) throughout the entire length of the river. The study area was restricted to the lower two kilometers where salinity ranges from 22-32 ppt, thereby reducing heterogeneity among sampling sites.

Living shoreline treatments $(\mathrm{n}=2)$ were selected, designed, and installed during April 2014 by The Nature Conservancy, Rhode Island Chapter and US Fish and Wildlife Service from Hurricane Sandy Recovery Funding. LS treatments were 
composed of coir logs made of natural coconut fiber that were staked down parallel to the marsh edge with three piles of oyster and clam shell each $2.44 \mathrm{~m}$ long, placed six meters apart abutting the coir logs. HS treatments $(\mathrm{n}=3)$ consisted of rock shoreline with vegetation landward of the structure. Natural, non-eroded shoreline was not present in the study area. Instead, we selected minimally eroded treatments (NS) as controls, which lacked current shoreline slumping and had vegetated banks but had some exposed roots on the marsh edge from sediment loss $(\mathrm{n}=2)$. We also selected highly eroded shoreline (ES) treatments $(n=3)$ as the second type of control that would be comparable to pre-shoreline armoring. Both types of control treatments were selected based on proximity (within the same salinity range) to the hardened and living shorelines and had similar physical shoreline characteristics. All of the treatment sites were located in the lower portion of the estuary, in the vicinity of the tidal inlet (Figure 1), to ensure that treatment effects were not confounded by environmental gradients along the estuary.

\section{Benthic Invertebrate Infauna}

Benthic infauna cores were analyzed to determine the benthic invertebrate community composition for density, richness, diversity and total biomass and were collected during May, August, and October of 2015 to also assess any seasonal variation. We used a sediment corer of known area $(6.5 \mathrm{~cm}$ diameter, $14 \mathrm{~cm}$ long) to subsample for species abundance and biomass. Cores were extracted haphazardly within $50 \mathrm{~cm}$ either side of replicate four meter-long transects (perpendicular to the shoreline) at zero meters (edge of shoreline), two meters, and four meters from the shore ( 3 cores / transect, 6 cores total / treatment / season) (Figure 2). Each sample 
was washed over a $250 \mu \mathrm{m}$ mesh sieve in the field. All material retained on the screen was stored in a labeled plastic $0.5 \mathrm{~L}$ container placed in a cooler and immediately transported back to the lab and stored at $4{ }^{0} \mathrm{C}$. Prior to processing, the samples were thawed and the organisms were removed from the sediment under a stereomicroscope (magnification range 10X-60X) and preserved in 70\% isopropyl alcohol and 30\% water (EPA, 2002; Pelletier et al., 2010). The organisms were identified under a stereomicroscope to the lowest practical taxonomic level, enumerated, and wet weighed (by lowest taxonomical level) (Patricio et al., 2009; Pollock, 1998; Weiss \& Bennett, 1995).

\section{Sediment Grain Size}

Sediment grain size core samples were collected using a $60 \mathrm{ml}$ syringe with a 2.6 cm diameter ( 2 / site, 1 meter from the edge of shoreline) and sliced into onecentimeter layers from the top five centimeters $(n=10 /$ site $)$. Grain size is useful for understanding processes related to transportation and deposition of sediment and as an indicator of the strength of hydrological flow (Neckles et al., 2013). With a higher current velocity fine grain particles are easily re-suspended leaving behind sediments of a larger grain size, which can determine the benthic infauna community present due to the decreased amount of fine organic matter and food availability (Wildish and Kristmanson, 1979). Grain size changes habitat suitability for benthic infauna; for example, filter feeders tend to prefer larger grain size whereas deposit feeders prefer finer grain size (Hyland et al., 2005).

\section{Sediment Carbon and Nitrogen}


Sediment carbon content is important as a source of food for benthic fauna (Pelletier et al., 2010; Ivan et al., 2013). However, high levels of nitrogen from decomposing primary producers can promote organic matter accumulation and lead to oxygen depletion, causing a shift in species composition along with a decrease in invertebrate species richness, density, and total biomass. Sediment carbon and nitrogen thus provide an indirect measurement of habitat quality (Deegan et al., 2012). Sediment core samples for carbon and nitrogen were collected using the same sampling scheme described above for the invertebrate core (distance between transects $\leq 1$ meter) using a $60 \mathrm{ml}$ syringe with a $2.6 \mathrm{~cm}$ diameter ( 2 transects / site, 3 cores / transect, 6 cores total / site).

The top five centimeters of each core were sliced into one-centimeter sections to analyze the core by depth. Sediment was oven dried in the lab at $50{ }^{0} \mathrm{C}$ for 48 hours or until completely dry. Once dry, the sediment was ground and homogenized using a mortar and pestle. Percent carbon and nitrogen were determined using a Costech elemental analyzer (Elemental Combustion System CHNS-O, ESC 4010) at the University of Rhode Island Coastal Institute (EPA, 2005).

\section{Water Quality}

Salinity, water temperature, and dissolved oxygen concentration were measured using a YSI Pro 2030 Handheld Dissolved Oxygen, Conductivity, Salinity, and Temperature System. Measurements were taken four meters from the edge of the shoreline at the surface and bottom when possible (water depth had to exceed $0.5 \mathrm{~m}$ otherwise homogeneity was assumed within the water column).

Data Analysis 
Replicate water quality, sediment percent carbon and nitrogen, and grain size were sampled at three points, $0 \mathrm{~m}, 2 \mathrm{~m}$, and $4 \mathrm{~m}$, from the shore edge along each of the two transects per treatment (site) during each season. The physical-chemical data were tested for assumptions of normality using the Levene's test of homogeneity of variances (Weisberg, 2011). When necessary, data were log transformed or run using the zero inflated Poisson for count data with an excessive number of zeros to ensure normality. The model assumes a mixture of two types of individuals, those with a zero probability of a count larger than zero and the other that has counts distributed by a Poisson regression (Wenger \& Freeman, 2008).

Three generalized mixed-effects (GLMER) models were performed on the physical-chemical attributes, which were assigned as response variables in both models with treatment (site) and season as random factors to determine whether there were statistically significant differences between treatments. The second model assigned treatment (site) as a fixed factor and season as a random factor to determine statistical significance of season. For the third model, sediment percent carbon and nitrogen and grain size values by collection depth and distance from shoreline were run with the mean core value nested within treatment (site) as a fixed factor to determine statistical significance, using R Studio (Team, 2014) software package lme4 (Bates et al., 2014) and plots of the data were created using the ggplot2 package (Wickham, 2009) and a p value $<0.05$ was used for determining statistical significance for all analyses. A Tukey multiple comparisons of means was performed to distinguish statistical significance between treatments. 
Total density (individuals $\left./ \mathrm{m}^{2}\right)$ and biomass $\left(\mathrm{g} / \mathrm{m}^{2}\right)$ were calculated as the mean of the two replicate cores collected within each treatment (site) $(n=6 /$ site) for each season. Shannon-Weiner Diversity Index $\left(H^{\prime}=-S U M\left[\left(p_{i}\right) \times \ln \left(p_{i}\right)\right] H^{\prime}=\right.$ $-\sum\left[p_{i} \times \ln p_{i}\right]$ where $p_{i}$ is the proportion of total sample represented by species $i$ ) and species richness $(S)$ was calculated for each core, using Primer-E (v. 7) software.

The benthic infauna community indices (density, biomass, species richness, and diversity) were run on two GLMER models. The first model had the benthic infauna community indices as response factors and treatment (site) as a fixed factor and season as a random factor to assess any seasonal influence on the benthic infauna, using a GLMER in R studio (Team, 2014) package lme4 (Bates et al., 2014) and plots of the data were created using the ggplot2 package (Wickham, 2009) and Excel (v. 14.5.4). In the second model, each of the benthic infauna community indices was run as a response factor to each of the physical-chemical attributes, which were fixed covariate factors with treatment (site) and season as nested fixed factors, so as to determine statistically significant relationships.

The species collected were placed into feeding guilds (filter feeder, deposit feeder, scavenger, omnivore, carnivore, and herbivore). We determined the mean abundance within guilds at each of the site treatments to determine differences between treatment type and benthic community functional groups.

\section{Results}

Water Quality

Water temperature $\left({ }^{0} \mathrm{C}\right)$ and salinity (ppt) were significantly different between site treatments within each of the sampling seasons and across all sampling seasons (Table 
1). Dissolved oxygen (DO) (mg/ L) was significantly different between site treatments during the spring and summer and across all seasons but not within the fall sampling (Table 1).

\section{Sediment Grain Size}

Grain size composition was significantly different between all site treatment types within each season (spring and fall) and across seasons $(\mathrm{p}<0.05, \mathrm{df}=2)$, indicating that shoreline treatment may be an important factor influencing nearshore grain size (Table 1). There was no seasonal variation in grain size within treatment type, except at the ES sites where there was a decrease in percent sand between spring and fall $(\mathrm{p}=$ $0.05, \mathrm{df}=2$ ). The grain size at hardened and LS sites were not significantly different from each other during the spring and fall (Table 1) and the NS was not significantly different from the ES during the spring and fall.

\section{Sediment Carbon and Nitrogen}

Sediment percent carbon was significantly different across treatment types for all seasons with significantly lower levels at HS and LS compared to ES and NS. There was no significant difference between treatments in the fall sampling because HS and LS more than doubled in percent carbon $(\mathrm{p}=0.46, \mathrm{df}=2)($ Table 1 and Figure 3$)$. However, there was no variation in percent carbon with depth at all treatments $(\mathrm{p}=$ $0.91, \mathrm{df}=2)$ but with distance from the marsh edge at the eroded $(\mathrm{p}<0.05, \mathrm{df}=2)$ and natural shorelines $(p=0.02 \mathrm{df}=2)$. Percent nitrogen was significantly different across treatment types for summer and fall but was not significantly different between treatments during the spring (Table 1 and Figure 4). This was caused by an increase in percent nitrogen at NS during the summer. The ES showed a high correlation between 
distance from shore and percent nitrogen $(\mathrm{p}<0.05 \mathrm{df}=2)$ with the highest concentrations of nitrogen closest to the marsh edge and decreasing with distance moving waterward. This was likely caused by the accumulation of peat material along the edges of the salt marsh that had slumped off into the water due to erosion.

\section{Benthic invertebrate infauna}

A total of 59 benthic invertebrate taxa were collected across all treatment types during 2015 (Table S5). The mean species richness (Table 2 and Figure 5) at the eroded and hardened shorelines was significantly different $(\mathrm{p}<0.05$, $\mathrm{df}=2)$ over the seasons (spring, summer and fall). Infauna density was significantly different between treatments during each season with higher densities found during the spring compared to the fall at all sites. Density at ES and NS was the same during the spring and summer and LS and NS were significantly different from each other. However, all site treatments were not significantly different between treatments during the fall (Table 2 and Figure 6). Shannon-Wiener diversity was significantly different between treatment types during each of the seasons with higher diversity in the spring compared to the fall (Table 2 and Figure 7). The mean biomass at each treatment was not significantly different between treatment types (Table 2 and Figure 8).

ES and HS site treatments had more mobile infauna such as amphipods (67 and 75 respectively) and gastropods ( 32 and 31 respectively) in comparison to the NS (25 amphipods and 20 gastropods) and LS (27 amphipods and 4 gastropods) treatments (Figure 9). The LS and NS treatments have a similar composition of the major faunal groups while ES and HS share a similar relationship. There was variation in functional feeding groups between the treatments. The NS and LS are both dominated 
by carnivores, filter feeders and deposit feeders while the ES and HS have more functional groups present with the most dominant being omnivores/scavengers (Figure $10)$.

The linear mixed effects model showed that there is a significant effect of site type on species richness $(\mathrm{p}<0.05, \mathrm{df}=2)$ and diversity due to variations in grain size between treatments. Percent silt and sand had a positive correlation coefficient with species richness and diversity. Water temperature also showed a significant effect on species richness $(\mathrm{p}<0.05, \mathrm{df}=2)$ with increasing temperatures leading to increased richness.

\section{Discussion}

Our research on the benthic infauna of the Narrow River has shown that the NS and LS treatments had lower overall mean benthic infauna density but also lower seasonal variation in species diversity, density and richness over time as observed for the ES and HS treatments. The larger fluctuations in benthic infauna density, richness and diversity observed at the ES and HS treatments suggest that there is lower habitat stability relative to the NS and LS treatments, a conclusion similar to other studies (Bilkovic and Mitchell, 2013; Savage et al., 2012) and explained by the intermediate disturbance hypothesis (Widdicombe and Melanie, 2001; Thistle, 1981). Habitat stability (decreased physical disturbance) can lead to more consistent species richness over time, which was observed the ES and LS treatments, and is important in maintaining estuaries natural ecosystem biodiversity and function (Nordstrom et al., 2014). However, the intermediate level of disturbance occurring at the ES and HS sites is maximizing or creating a higher level of species density, richness and diversity 
because of the coexisting species that thrive during early and late successional periods. Our data also showed that there were distinct differences in feeding guild structure between site treatments with NS and LS having a similar guild composition in comparison to the ES and HS, which also had a similar guild make-up. These differences between invertebrate community composition further supports that the use of LS restoration has the potential to provide a more stable and thus suitable habitat to the benthic infauna community than HS construction when compared to the NS treatment.

Salt marshes provide protection and food for many of the organisms found within the estuary and these organisms in turn modify marsh habitat by converting resources. For example, filter-feeders remove dissolved organic matter and break it down within the sediment (Pennings, 2001), releasing an important source of nitrogen in a nitrogenlimited salt marsh and provide nutrients to plants via nutrient enriched sediment. The top few centimeters of the benthic sediment in a non-impacted estuary is a very active region full of invertebrates where the nutrient rich soil provides food and protection. These invertebrates are a very important food source for many larger species of nekton, especially during high tide and summer months when nekton are most active, which can restrict the abundance of benthic infauna (Nordstrom et al., 2014; Pennings, 2001).

Typically, in temperate latitudes peak benthic invertebrate recruitment occurs during the late spring with a decrease during the summer due to increased predation. A final small peak in abundance may occur during the fall before declining during the winter months (Sarda, 1995; Yang et al., 2008). This general pattern was observed at 
our four site treatments in the Narrow River. However, the ES and HS treatment types had constant decreases in their density from May through October, with a significant difference between the May sampling and October sampling. The pattern was the same at the LS and NS treatments but with overall lower density, indicating that higher levels of disturbance found at the ES and HS are leading to higher density in the spring but as resources are depleted and predation increases these treatments lose more than half of their density by the fall (Nordstrom et al., 2014; Olsen et al., 2013; Widdicombe and Melanie, 2001; Thistle, 1981).

Omnivores and scavengers were the most prominent at the ES and HS treatments, with species such as the annelid Streblospio benedicti and amphipods Lysianopsis alba and Asterope mariae. Pennings (2001) showed that surface layer sediments dominated by fine silt or large cobble (such as those found at ES and HS respectively) are less stable and more susceptible to disturbance and thus less likely to support a stable benthic infauna community (Neira, 2006; Scyphers et al., 2011; Thistle, 1981). Over time this could lead to lower recruitment at these treatment types during the summer months with a gradual decline in species richness and density over time. Most of the species found within the living and natural shoreline sites consisted of filter feeders and carnivores such as Hypereteone heteropoda and Polydora cornuta, which are capable of burrowing below the surface sediment to escape from predators (Seitz et al., 2006).

Due to the pressure of predation by larger nekton species (i.e. blue crabs and striped bass), smaller nekton that feed on benthic invertebrates tend to take refuge in areas of the marsh with more complex structure, such as the LS, or vegetated habitats, 
like those found at the NS (Olsen et al., 2013; Seitz et al., 2006). Increased predation at the NS and LS treatments compared to the ES and HS treatments could explain the lower diversity and biomass found at NS and LS. Although we did not survey the nekton population at these sites, the increased feeding pressure by the nekton community during the summer most likely caused the significant decline observed in density at the ES and HS between May and October (Mulkana, 1966; Sarda, 1995; Seitz et al., 2006).

The significant differences in grain size and sediment percent carbon and nitrogen content between the treatment types over all time points shows that site treatment type influences the sediment grain size and thus the sediment percent carbon (Schaggner, 2009). Each of the sites had significant differences in percent clay, silt, and sand, between the treatment types, with more sand found at the HS compared to the NS and the most sand observed at the newly restored LS. Variations in the sediment grain size can be indicative of the dominant benthic infauna and feeding guild structure (Chang et al., 1992; Scyphers et al., 2011), which was apparent in the distinctly different feeding guild compositions between treatment types. The NS and LS showed similar feeding guild dominance with the most filter feeders (25\% and $32 \%$ respectively), deposit feeders and carnivores compared to the eroded and hardened shorelines, which were more diverse but without a distinct dominant feeding structure. The difference in feeding guild structure between the NS and HS indicate that the nearshore habitat value and functioning of the ecosystem could be impacted by the introduction of the hardened structure (Gittman et al., 2016; Bilkovic and Mitchell, 2013; Bilkovic and Roggero, 2008). 
The HS and ES are in a more constant state of habitat disturbance compared to the NS and LS, which can lead to greater diversity and trophic complexity in the benthic infauna community indices found at the HS and ES sites (Widdicombe and Melanie, 2001; Thistle, 1981). A previously highly disturbed habitat usually leads to a narrowing of habitat once the disturbance is removed and the habitat reaches a more stable state, which causes a decrease in diversity as the species become more specialized based on resource availability (food sources) (Nordstrom et al., 2014; Widdicombe and Melanie, 2001). From the observations in diversity, biomass and feeding guilds (decreased diversity and biomass with fewer and more specialized feeding guilds) present at the living shoreline treatment it appears that the habitat has reached the specialized niche point found post perturbation. These similarities between the living and natural shoreline in species density, diversity, biomass and feeding guild structure suggest a decreased impact of disturbance occurring at the living shoreline (Gittman et al., 2016; Widdicombe and Melanie, 2001; Thistle, 1981).

The eroded shoreline treatment type had a higher mean C:N ratio than the other treatment types most likely related to the constant addition of peat into the water column and sediment surface from the slumping marsh edge, as is an increasingly common feature of New England marshes (Deegan et al., 2012). The amount of carbon within the sediment is associated with the amount of organic matter, however there is a threshold for the quality as well as the quantity of carbon because this can impact its utilization as a food source (Hyland et al., 2005). If the quality of organic matter present within the sediment, such as that derived from peat of the eroded marsh, is not an efficient food source that can sustain a diverse infauna community it 
would lead to a lower diversity community with a more variable, and in time, diminished distribution of their density as resources are utilized in one area (Craft and Sacco, 2003; Hyland et al., 2005). This is not what was observed at the ES treatment during the May sampling, however this could explain the larger decrease in density between the May and October sampling than at the NS and LS. According to previous studies, it is expected that areas with levels of organic carbon reaching above $35 \mathrm{mg} \mathrm{g}^{-}$ ${ }^{1}$ or below $10 \mathrm{mg} \mathrm{g}^{-1}$, should see lower levels of species richness than intermediate levels within this range (Hyland et al., 2005). The seasonal variation seen within our sites for percent $\mathrm{C}, \mathrm{N}$, and $\mathrm{C}: \mathrm{N}$ ratio is possibly due to the natural increase in benthic processing by benthic invertebrates and the microbial community as temperatures increase in the upper sediment layers during the summer (Zimmerman \& Benner 1994).

After marsh restoration, such as the living shoreline restoration in this study, a minimum of five years is considered necessary for secondary producers to reach similar functional feeding group structures compared to the natural marsh (Craft and Sacco, 2003; Mitchell, 2013). We observed greater infauna density at the HS (which was constructed before the installed living shoreline) compared to the LS treatment site, however the LS treatments were installed at highly impacted areas, and it may take more than one to two years to observe any significant changes in the benthic invertebrate community assemblages because of colonization time (Lawless and Seitz, 2014; Nordstrom et al., 2014). Benthic invertebrates are often used as ecosystem health indicators, however they are slow to redevelop community composition comparable to natural marshes (Craft and Sacco, 2003). Slower rates of 
recolonization are caused by the lack of fast dispersal along with lower organic matter present in disturbed marsh soils (Craft and Sacco, 2003). The invertebrate core samples for this project were collected just one year after the installation of the living shoreline so as to obtain baseline data, which means that it is still in the recovery and assimilation phase. Ideally, these surveys should continue a minimum of five years post installation to allow the benthic invertebrates an adequate response time to the LS treatment (Bilkovic et al., 2006; Bilkovic and Mitchell; 2013; Craft and Sacco 2003). This would allow for a more accurate representation of LS restoration potential for benthic invertebrate assemblages.

As coastal communities face sea level rise, more intense hurricanes and storm surges we continue to see a decline in the overall ability of salt marshes to provide the important protective habitat to a variety of estuarine species (Bilkovic \& Roggero, 2008). Within the state of Rhode Island, approximately 25\% (96 miles out of the total 384) of the coastline is hardened (Save The Bay, 2013), however, the state has now started to limit the use of hardened shorelines due to regulations instated by CRMC (CRMC, 2015; NOAA, 2016). We continue to develop new ways of protecting our shorelines and it will be important to factor in the impact these structures have on the benthic infauna, since they are of fundamental importance to coastal food webs (Currin, 2010; Mitchell, 2013; Pelletier et al., 2010).

Complete shoreline hardening has been shown to decrease species diversity within the benthic infauna community but a hybridized version of shoreline armoring has potential to add stability to the shoreline and provide habitat to a more diverse and sustainable benthic infauna community (Chang et al., 1992; Craft and Sacco, 2003; 
Dugan et al., 2008). For future restoration projects, monitoring the benthic infauna community provides an important insight into the overall habitat quality and recovery phase within the site of interest because of their sensitivity to changes in the local environment and can be used as a benchmark for restoration success of habitat quality (Mitchell, 2013).

Marine benthic infauna are important secondary producers in the marine estuarine environment (Craft and Sacco, 2003; Sarda, 1995) and serve as the link between primary producers and important commercial fisheries species that depend on highly productive estuarine nursery habitats. The abundance of many estuarine flora and fauna are declining (Bertness, 2002; Mitchell, 2013; USFW, 2014) primarily due to expanding human coastal population density, increases in infrastructure, and other anthropogenic activity. These human disturbances have weakened the natural protective barrier of salt marshes by disrupting the link between aquatic and terrestrial buffers (Bilkovic \& Roggero, 2008; Savage et al., 2012; Swann, 2008; USFW, 2014). Current salt marsh restoration practices using living shorelines seek to recreate the natural structural and functional processes of salt marshes. Although living shoreline restoration is a young science the importance of understanding invertebrate infauna communities will help us restore natural function and habitat. 
Table 1. Means $( \pm \mathrm{SD})$ of chemical (salinity (ppt), DO (mg/L) and temperature $\left({ }^{0} \mathrm{C}\right)$ ) and physical measurements analyzed with a two-way ANOVA by treatment within and between sampling months. A Tukey Multiple comparisons of means was performed to determine significance between treatments. Sediment data were averaged by core for analysis. Variables with similar superscripts are not significantly different among treatments.

\begin{tabular}{|c|c|c|c|c|c|c|c|c|c|}
\hline & \multirow[t]{2}{*}{ Treatment } & \multirow[t]{2}{*}{ Salinity } & \multirow[t]{2}{*}{ DO } & \multirow[t]{2}{*}{ Temp } & \multicolumn{5}{|c|}{ Sediment } \\
\hline & & & & & $\%$ Clay & $\%$ Silt & $\%$ Sand & $\% \mathrm{~N}$ & $\% \mathrm{C}$ \\
\hline \multirow[t]{5}{*}{ Spring } & ES & $25.1(3.1)^{\mathrm{a}}$ & $6.8(0.1)^{\mathrm{a}}$ & $23.9(2.2)^{\mathrm{a}}$ & $0.4(0.2)^{\mathrm{ab}}$ & $16.9(7.5)^{\mathrm{ab}}$ & $84.5(9.3)^{\mathrm{ab}}$ & $0.2(0.2)$ & $3.4(3.6)^{\mathrm{a}}$ \\
\hline & HS & $30.8(1.3)^{b}$ & $8.5(1.4)^{b}$ & $22.4(1.4)^{\mathrm{ab}}$ & $0.4(0.3)^{\mathrm{a}}$ & $15.2(11.6)^{\mathrm{a}}$ & $83.3(10.6)^{\mathrm{a}}$ & $0.1(0.1)$ & $1.5(0.9)^{\mathrm{ab}}$ \\
\hline & LS & $23.1(0.0)^{\mathrm{a}}$ & $7.3(0.0)^{\mathrm{a}}$ & $22.5(0.0)^{\mathrm{ab}}$ & $0.0(0.1)^{\mathrm{a}}$ & $5.0(3.0)^{\mathrm{a}}$ & $95.1(3.1)^{\mathrm{a}}$ & $0.1(0.1)$ & $0.9(0.4)^{b}$ \\
\hline & NS & $25.5(0.0)^{\mathrm{a}}$ & $6.2(0.0)^{\mathrm{a}}$ & $20.6(0.0)^{b}$ & $0.7(0.7)^{b}$ & $23.8(24.1)^{\mathrm{b}}$ & $75.6(24.8)^{b}$ & $0.2(0.2)$ & $2.8(2.5)^{\mathrm{ab}}$ \\
\hline & $p$-value & $<0.05$ & $<0.05$ & $<0.05$ & $<0.05$ & $<0.05$ & $<0.05$ & 0.34 & $<0.05$ \\
\hline \multirow[t]{5}{*}{ Summer } & ES & $31.2(0.0)^{\mathrm{a}}$ & $0.4(0.0)^{\mathrm{a}}$ & $26.5(0.0)^{\mathrm{a}}$ & & & & $0.2(0.1)^{\mathrm{ab}}$ & $2.7(1.9)^{\mathrm{a}}$ \\
\hline & HS & $29.8(0.0)^{b}$ & $10.9(0.0)^{b}$ & $29(0.0)^{b}$ & & & & $0.1(0.1)^{\mathrm{a}}$ & $1.2(0.6)^{b}$ \\
\hline & LS & $30.7(0.0)^{\mathrm{c}}$ & $13.9(0.0)^{\mathrm{c}}$ & $28.4(0.0)^{\mathrm{a}}$ & & & & $0.2(0.1)^{\mathrm{a}}$ & $1.4(0.4)^{\mathrm{ab}}$ \\
\hline & NS & $30.7(0.0)^{c}$ & $6.0(0.0)^{d}$ & $24.1(0.0)^{\mathrm{c}}$ & & & & $0.7(0.9)^{b}$ & $3.0(2.3)^{\mathrm{a}}$ \\
\hline & $p$-value & $<0.5$ & $<0.5$ & $<0.5$ & & & & $<0.5$ & $<0.5$ \\
\hline \multirow[t]{5}{*}{ Fall } & ES & $29.7(2.3)^{\mathrm{a}}$ & $7.8(0.9)$ & $15.0(0.5)^{\mathrm{a}}$ & $0.5(0.4)^{\mathrm{a}}$ & $21.6(11.2)^{\mathrm{a}}$ & $77.9(11.6)^{\mathrm{a}}$ & $0.3(0.4)^{\mathrm{a}}$ & $1.8(1.2)$ \\
\hline & HS & $30.3(1.1)^{\mathrm{ab}}$ & $8.0(1.1)$ & $14.4(0.7)^{b}$ & $0.5(0.4)^{\mathrm{ab}}$ & $16.3(12.2)^{\mathrm{ab}}$ & $83.7(12.5)^{\mathrm{ab}}$ & $0.3(0.3)^{\mathrm{a}}$ & $3.4(3.8)$ \\
\hline & LS & $32.0(0.6)^{b}$ & $8.0(2.9)$ & $15.4(6.3)^{\mathrm{a}}$ & $0.1(0.0)^{b}$ & $6.4(1.2)^{\mathrm{b}}$ & $96.5(2.1)^{b}$ & $0.2(0.1)^{\mathrm{a}}$ & $2.2(2.1)$ \\
\hline & NS & $25.6(2.7)^{\mathrm{c}}$ & $8.6(0.3)$ & $12.7(0.3)^{c}$ & $0.8(0.8)^{\mathrm{a}}$ & $25.6(25.9)^{\mathrm{a}}$ & $73.7(26.7)^{\mathrm{a}}$ & $0.3(0.3)^{b}$ & $3.5(3.6)$ \\
\hline & p-value & $<0.5$ & 0.08 & $<0.5$ & $<0.5$ & $<0.5$ & $<0.5$ & $<0.5$ & 0.46 \\
\hline $\begin{array}{l}\text { All time } \\
\text { points }\end{array}$ & $p$-value & $<0.05$ & $<0.05$ & $<0.05$ & $<0.5$ & $<0.5$ & $<0.5$ & $<0.5$ & $<0.5$ \\
\hline
\end{tabular}


Table 2. Mean density (individuals $/ \mathrm{m}^{2}$ ), biomass $\left(\mathrm{g} / \mathrm{m}^{2} /\right.$ core), richness, and Shannon-Wiener diversity (H') ( \pm SD) of all species collected at each treatment in the Narrow River, RI 2015 by date.

\begin{tabular}{|c|c|c|c|c|c|}
\hline Date & Treatment & Density & Biomass & Richness & $\begin{array}{c}\text { Shannon-Wiener } \\
\text { Diversity }\end{array}$ \\
\hline \multirow{4}{*}{ Spring } & ES & $43.67(40.33)^{\mathrm{ab}}$ & $0.11(0.11)$ & $6.72(3.32)^{\mathrm{a}}$ & $1.29(0.62)^{\mathrm{a}}$ \\
\hline & HS & $65.78(74.41)^{\mathrm{a}}$ & $0.09(0.07)$ & $2.39(3.87)^{\mathrm{ab}}$ & $1.25(0.67)^{\mathrm{ab}}$ \\
\hline & LS & $17.50(18.45)^{b}$ & $0.06(0.06)$ & $1.78(2.53)^{\mathrm{ab}}$ & $0.86(0.61)^{\mathrm{ab}}$ \\
\hline & NS & $20.00(28.22)^{\mathrm{ab}}$ & $0.06(0.10)$ & $1.51(3.65)^{b}$ & $0.63(0.61)^{b}$ \\
\hline \multirow{6}{*}{ Summer } & $p$-value & 0.03 & 0.49 & 0.01 & 0.02 \\
\hline & ES & $26.83(29.15)^{\mathrm{ab}}$ & $0.07(0.11)$ & $1.29(2.03)^{\mathrm{a}}$ & $0.36(0.45)^{\mathrm{a}}$ \\
\hline & HS & $39.67(28.19)^{b}$ & $0.37(1.14)$ & $2.59(3.07)^{b}$ & $1.39(0.54)^{b}$ \\
\hline & LS & $6.33(7.23)^{\mathrm{a}}$ & $0.09(0.25)$ & $1.29(2.02)^{\mathrm{a}}$ & $0.74(0.55)^{\mathrm{a}}$ \\
\hline & NS & $22.92(36.12)^{\mathrm{ab}}$ & $0.04(0.06)$ & $1.53(2.66)^{\mathrm{a}}$ & $0.56(0.58)^{\mathrm{a}}$ \\
\hline & $p$-value & 0.02 & 0.41 & $<0.05$ & $<0.05$ \\
\hline \multirow{5}{*}{ Fall } & ES & $7.50(12.98)$ & $0.26(0.26)$ & $0.89(1.98)^{\mathrm{a}}$ & $0.40(0.50)^{\mathrm{a}}$ \\
\hline & HS & $13.11(16.79)$ & $1.02(4.18)$ & $1.74(2.17)^{b}$ & $0.81(0.66)^{b}$ \\
\hline & LS & $7.75(13.72)$ & $0.01(0.01)$ & $0.97(1.51)^{\mathrm{a}}$ & $0.30(0.35)^{\mathrm{a}}$ \\
\hline & NS & $8.08(8.15)$ & $0.29(0.94)$ & $1.28(1.56)^{\mathrm{a}}$ & $0.60(0.56)^{\mathrm{a}}$ \\
\hline & $p$-value & 0.58 & 0.60 & 0.02 & 0.05 \\
\hline $\begin{array}{l}\text { All time } \\
\text { points }\end{array}$ & $p$-value & 0.001 & 0.37 & $<0.05$ & $<0.05$ \\
\hline
\end{tabular}




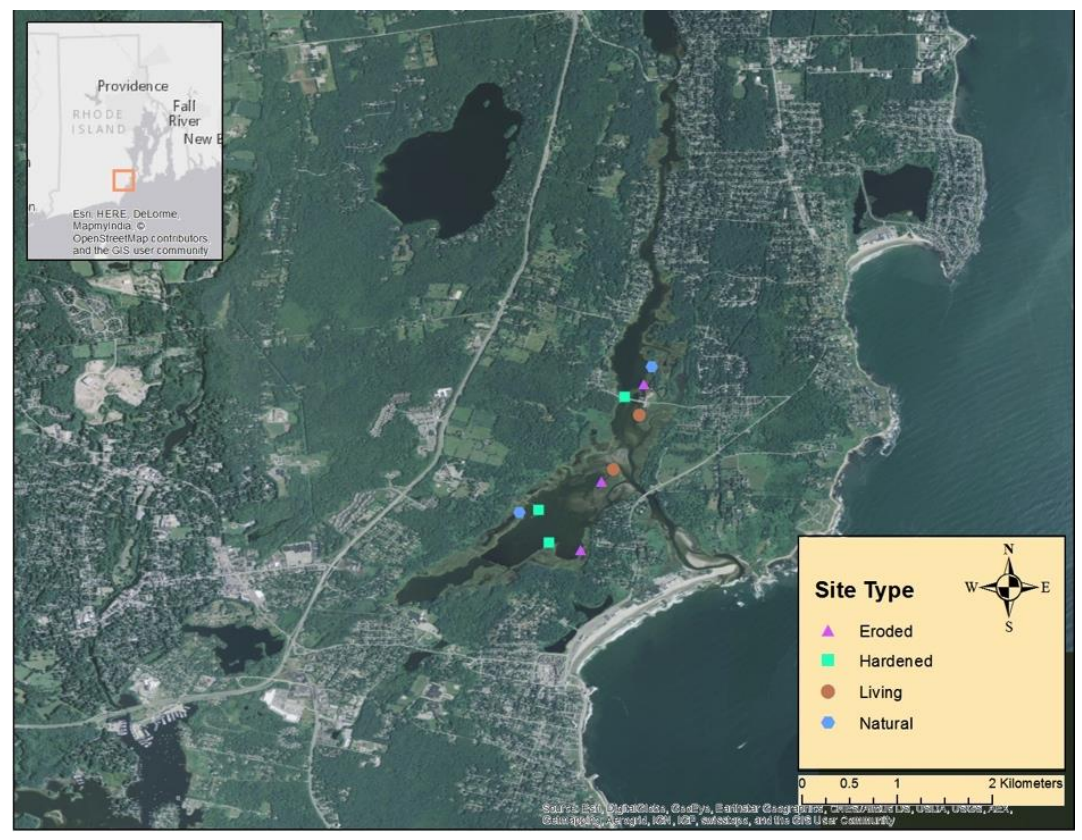

Figure 1. Site treatment types and their locations within the Narrow River, Rhode Island. 


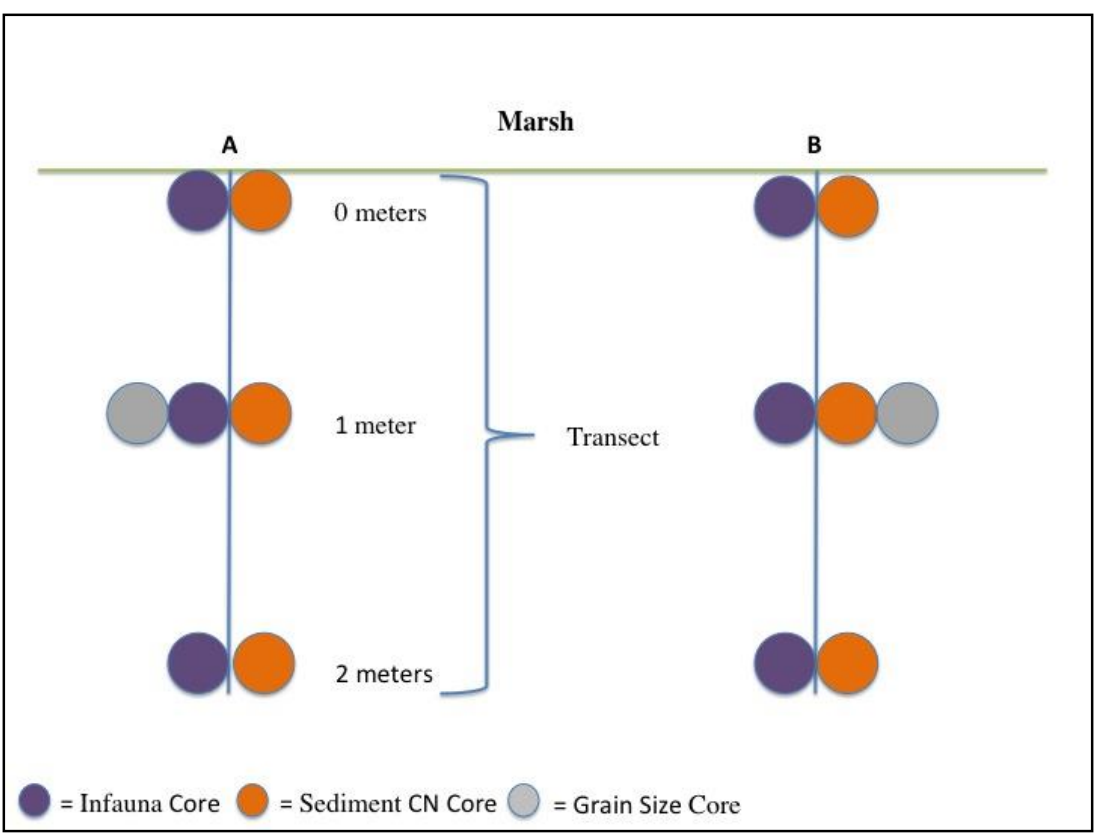

Figure 2. Transect and core sample collection design applied at each of the shoreline treatments. Replicate transects are labeled as A and B. 


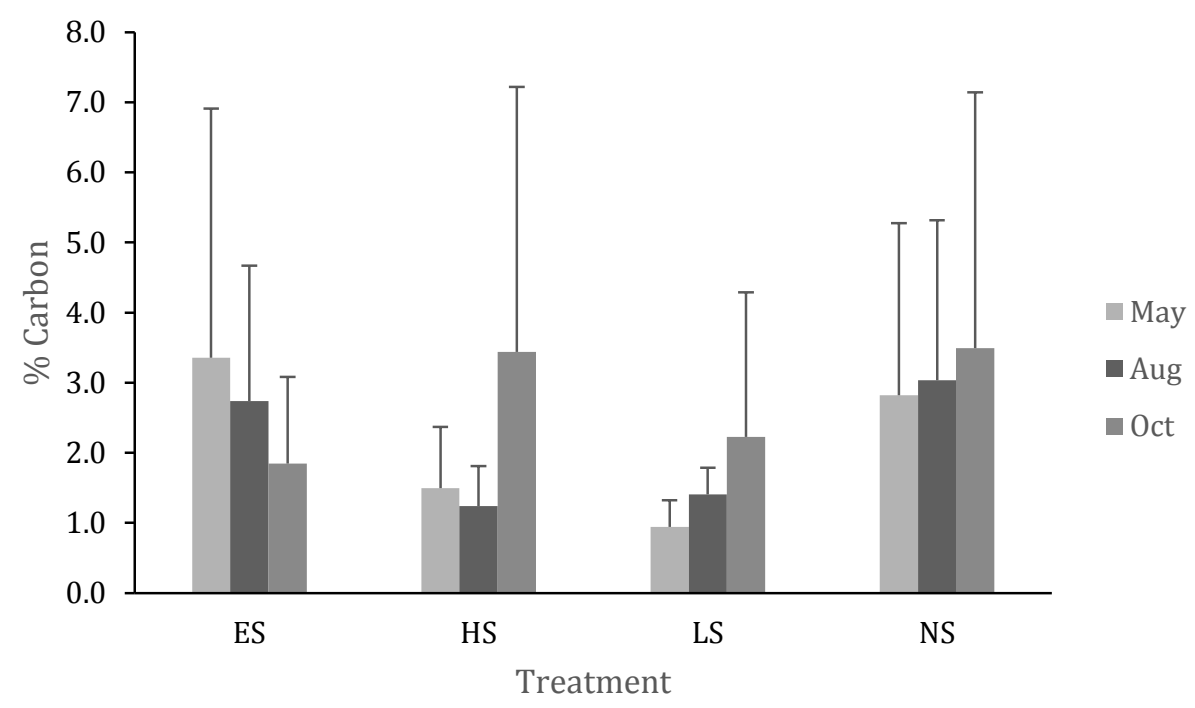

Figure 3. Mean sediment percent carbon $( \pm$ SD) for each treatment at each sampling period during $2015(\mathrm{df}=2)$. $\mathrm{p}_{\text {treatment*may }}<0.05$, $\mathrm{p}_{\text {treatment*aug }}<0.05$, and $\mathrm{p}_{\text {treatment*oct }}=$ 0.46 . 


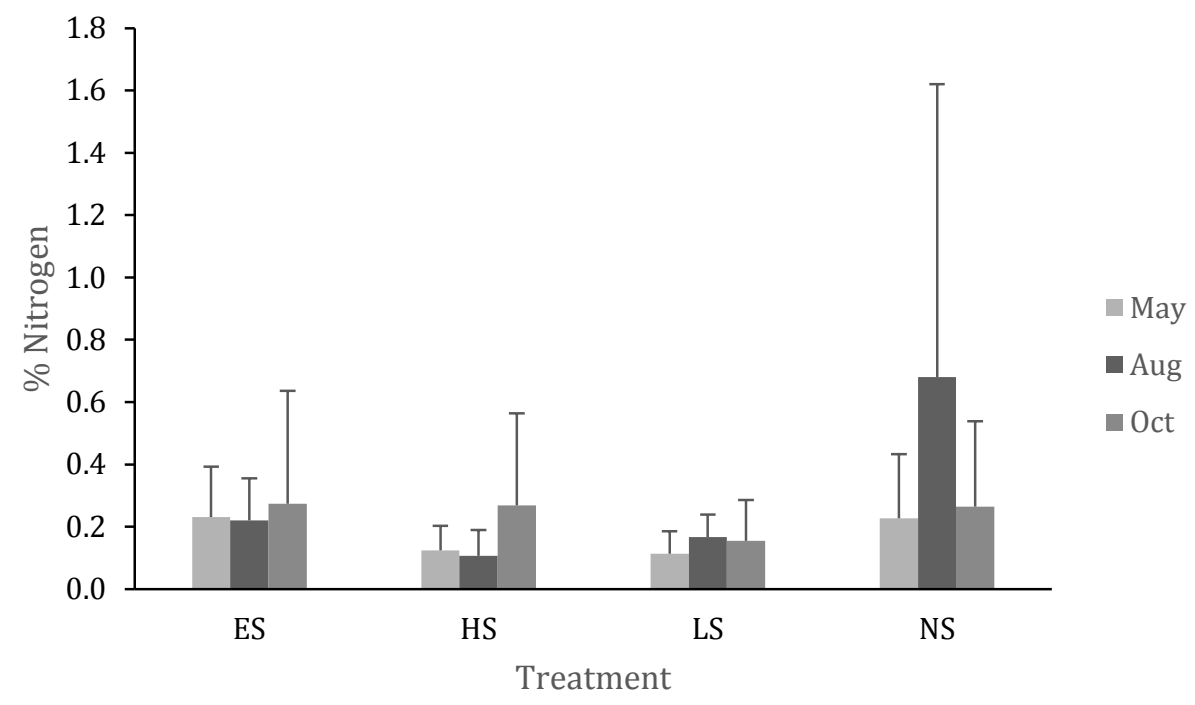

Figure 4. Mean sediment percent nitrogen $( \pm \mathrm{SD})$ for each treatment at each sampling

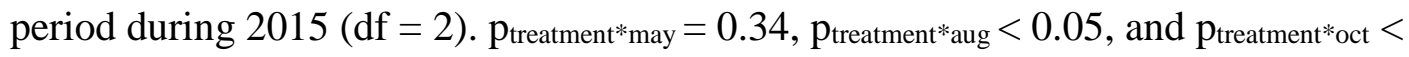
0.05 . 


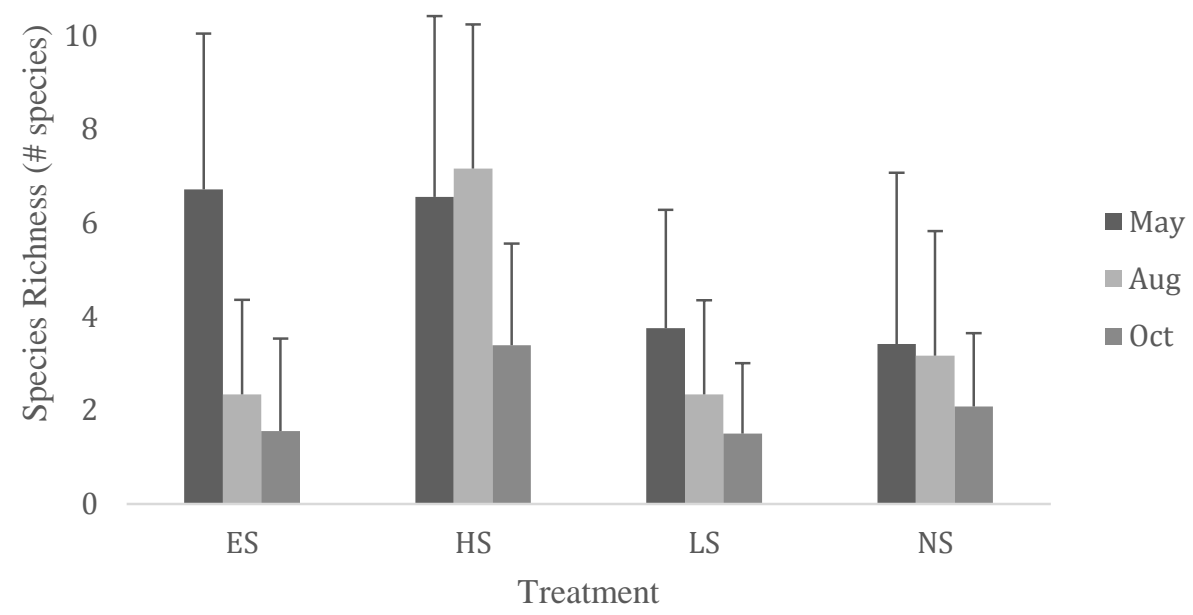

Figure 5. Mean species richness $( \pm \mathrm{SD})$ at each treatment at each sampling period during 2015. The eroded and hardened shoreline had significant differences in

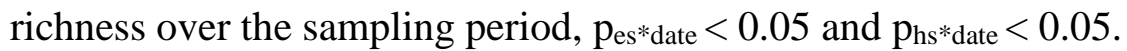




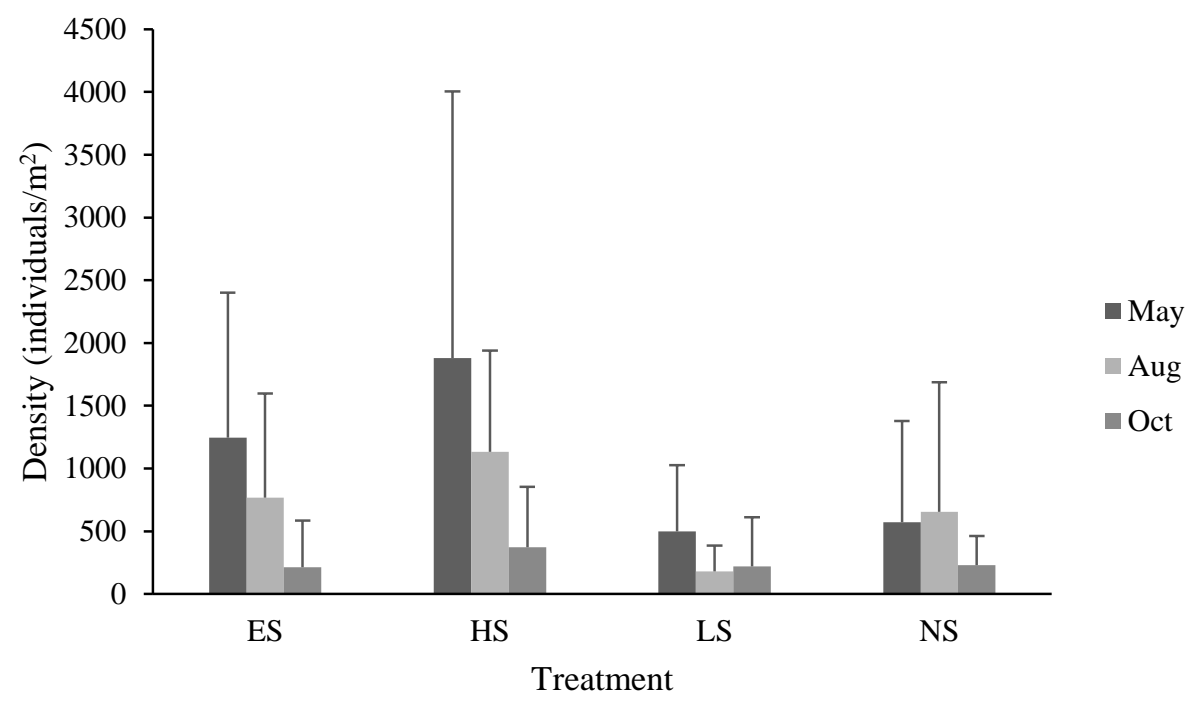

Figure 6. Mean infauna density (individuals $\left./ \mathrm{m}^{2}\right)( \pm \mathrm{SD})$ at each treatment at each sampling period during 2015. P-value for density between treatments is significant ( $\mathrm{p}$ $<0.05, \mathrm{df}=2)(\log +1$ transformed $)$. 


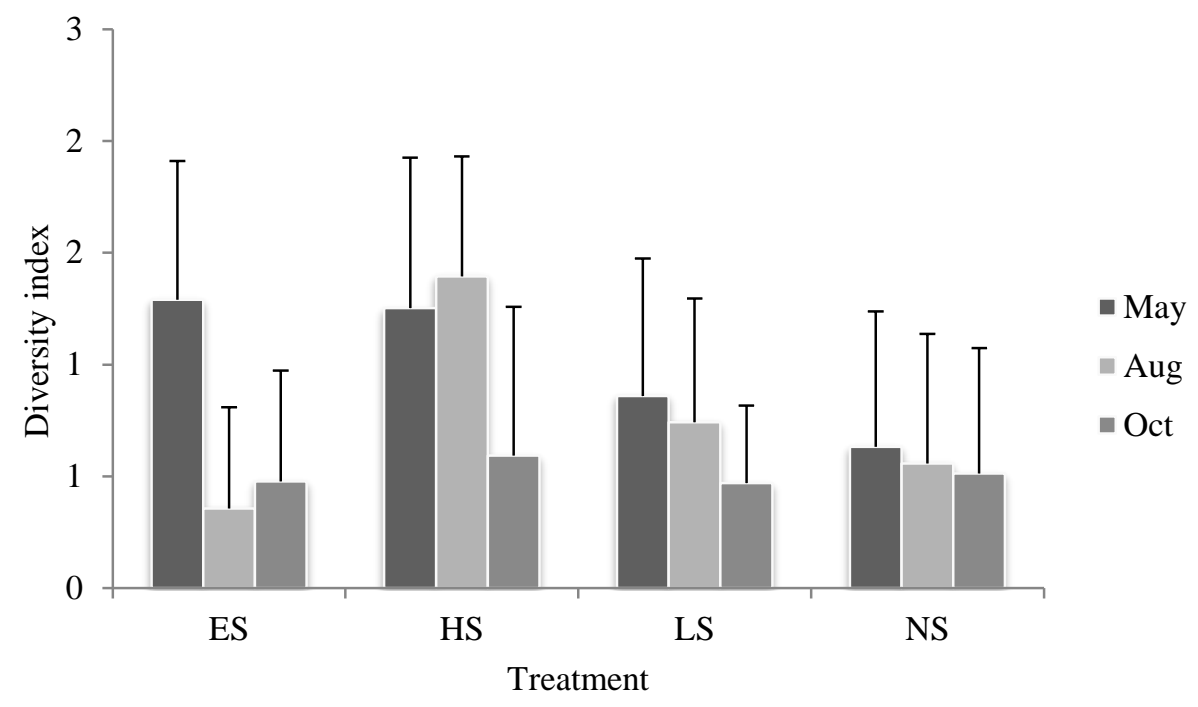

Figure 7. Mean Shannon-Wiener diversity values $( \pm$ SD) at each treatment at each sampling period during 2015. P-value for Shannon-Weiner diversity between the treatments during each season is significant $(\mathrm{p}<0.05, \mathrm{df}=2)$. 


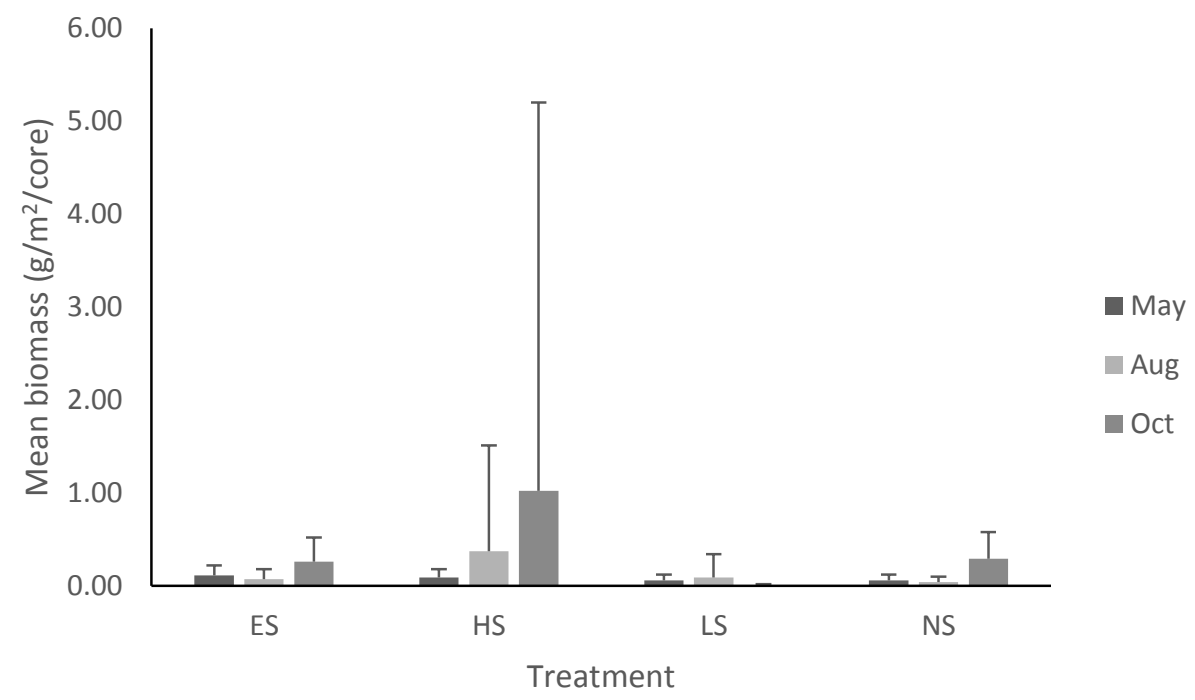

Figure 8. Mean biomass $( \pm \mathrm{SD})$ at each treatment at each sampling period during 2015. 


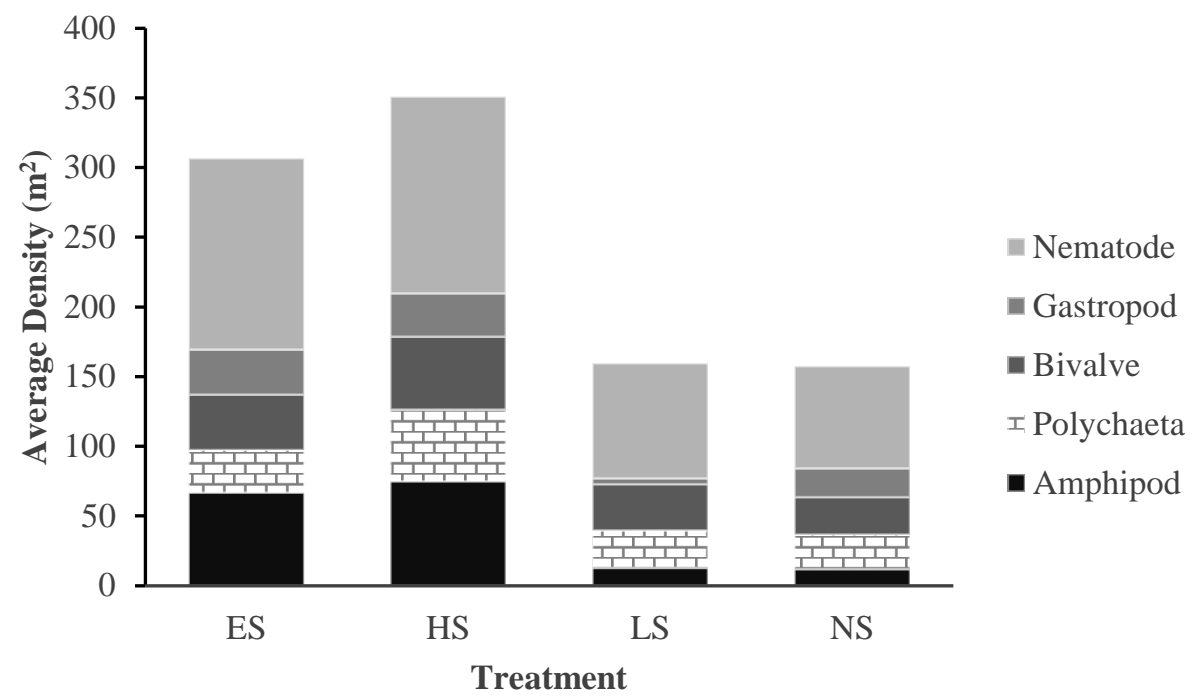

Figure 9. The distribution of dominant infauna at each treatment from the three sampling periods during 2015 in the Narrow River, RI. 


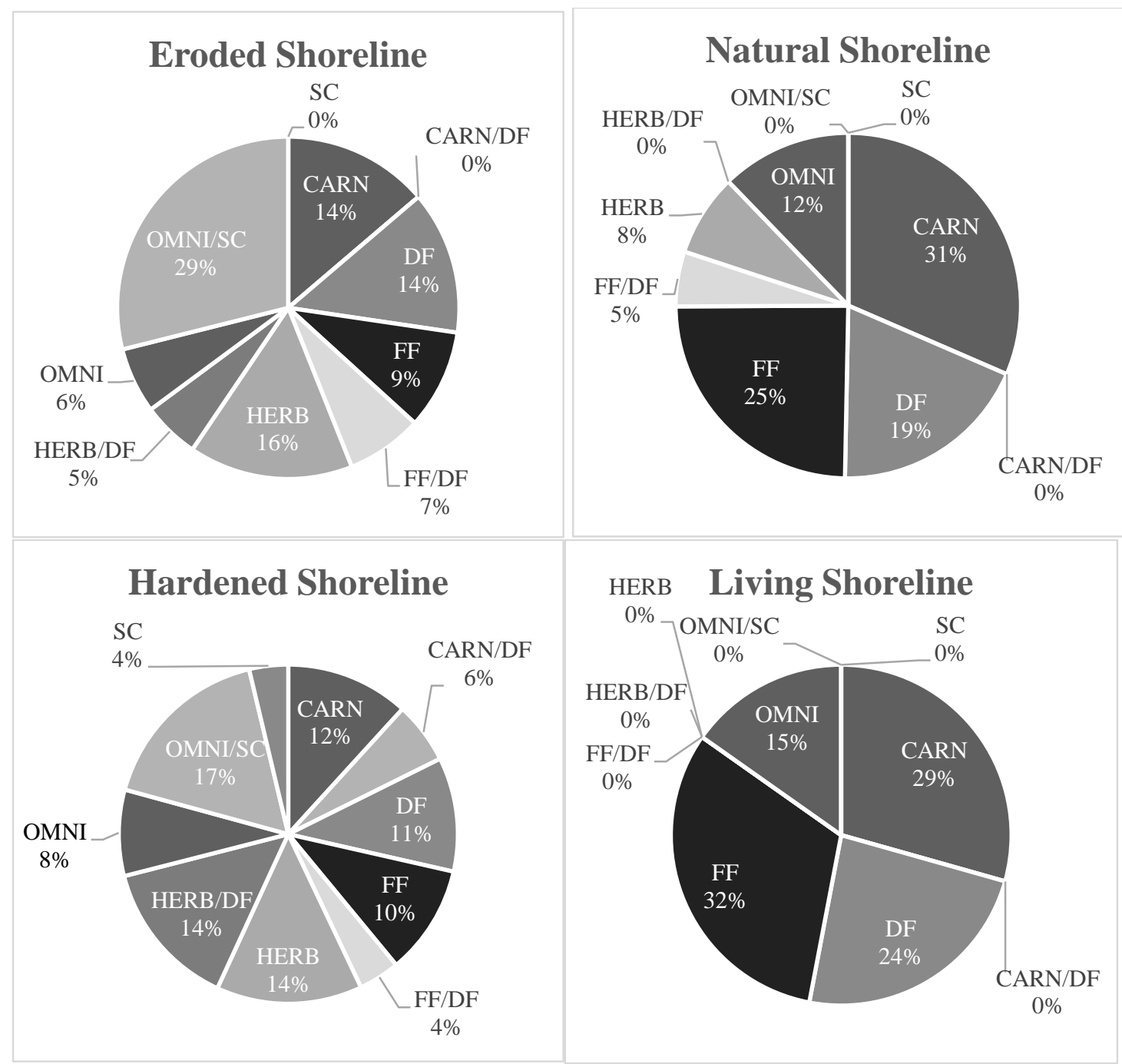

Figure 10. Mean species functional group distribution at each treatment from May, August, and October 2015. Filter feeder (FF), deposit feeder (DF), scavenger (SC), omnivore (OMNI), carnivore (Carn), herbivore (HERB). 
APPENDICES 
Table S1. Welch two-sample t-test of grain size during May and October 2015 with mean grain size $( \pm \mathrm{SD})$ at each of the site treatments. Significant $\mathrm{p}$-values are indicated in bold.

\begin{tabular}{|c|c|c|c|c|c|}
\hline \multicolumn{6}{|c|}{ Mean } \\
\hline \multirow{4}{*}{$\begin{array}{c}\text { Eroded } \\
\text { Shoreline }\end{array}$} & & May & October & p-value & df \\
\hline & clav & $0.38(0.27)$ & $0.54(0.42)$ & 0.07 & 2 \\
\hline & silt & $16.86(9.12)$ & $21.58(13.25)$ & 0.11 & 2 \\
\hline & sand & 84.49 (11.19) & 77.87 (13.65) & 0.05 & 2 \\
\hline \multirow{3}{*}{$\begin{array}{c}\text { Hardene } \\
\quad \mathrm{d} \\
\text { Shoreline }\end{array}$} & clay & $0.37(0.44)$ & $0.52(0.90)$ & 0.41 & 2 \\
\hline & silt & $15.21(14.99)$ & $16.34(21.09)$ & 0.81 & 2 \\
\hline & sand & 83.31 (15.47) & $83.67(20.01)$ & 0.94 & 2 \\
\hline \multirow{3}{*}{$\begin{array}{c}\text { Living } \\
\text { Shoreline }\end{array}$} & clay & $0.04(0.08)$ & $0.06(0.09)$ & 0.51 & 2 \\
\hline & silt & $4.97(4.04)$ & $6.38(2.26)$ & 0.19 & 2 \\
\hline & sand & $95.06(4.10)$ & 96.47 (8.23) & 0.50 & 2 \\
\hline \multirow{3}{*}{$\begin{array}{l}\text { Natural } \\
\text { Shoreline }\end{array}$} & clay & $0.66(0.71)$ & $0.77(0.84)$ & 0.67 & 2 \\
\hline & silt & 23.76 (23.99) & $25.56(25.91)$ & 0.82 & 2 \\
\hline & sand & $75.58(24.69)$ & $73.67(26.73)$ & 0.82 & 2 \\
\hline
\end{tabular}


Table S2a. One-way ANOVA analysis of sediment \% C (carbon) collected during May, August and October 2015. Significant $\mathrm{p}$-values indicated in bold ( $\mathrm{df}=$ degrees of freedom).

\begin{tabular}{|c|c|c|c|}
\hline \multirow{4}{*}{$\begin{array}{l}\text { Eroded } \\
\text { Shoreline }\end{array}$} & & $\mathrm{p}$-value & df \\
\hline & Core Distance & $<0.05$ & 2 \\
\hline & Date Collected & $<0.05$ & 2 \\
\hline & Core Depth & 0.91 & 2 \\
\hline \multirow{3}{*}{$\begin{array}{l}\text { Hardened } \\
\text { Shoreline }\end{array}$} & Core Distance & 0.31 & 2 \\
\hline & Date Collected & $<0.05$ & 2 \\
\hline & Core Depth & 0.99 & 2 \\
\hline \multirow{3}{*}{$\begin{array}{c}\text { Living } \\
\text { Shoreline }\end{array}$} & Core Distance & 0.14 & 2 \\
\hline & Date Collected & $<0.05$ & 2 \\
\hline & Core Depth & 0.14 & 2 \\
\hline \multirow{3}{*}{$\begin{array}{l}\text { Natural } \\
\text { Shoreline }\end{array}$} & Core Distance & 0.02 & 2 \\
\hline & Date Collected & $<0.05$ & 2 \\
\hline & Core Depth & 0.21 & 2 \\
\hline
\end{tabular}


Table S2b. One-way ANOVA of sediment \% N (Nitrogen) collected during May, August and October 2015. Significant $\mathrm{p}$-values are indicated in bold $(\mathrm{df}=$ degrees of freedom).

\begin{tabular}{|clcc|}
\hline \multirow{4}{*}{ Eroded } & p-value & df \\
\cline { 3 - 4 } Shoreline & Core Distance & $\mathbf{< 0 . 0 5}$ & 2 \\
& Date Collected & 0.52 & 2 \\
& Core Depth & 0.78 & 2 \\
\hline \multirow{2}{*}{ Hardened } & Core Distance & 0.29 & 2 \\
Shoreline & Date Collected & $\mathbf{< 0 . 0 5}$ & 2 \\
& Core Depth & 0.97 & 2 \\
\hline \multirow{2}{*}{ Living } & Core Distance & 0.56 & 2 \\
Shoreline & Date Collected & 0.42 & 2 \\
& Core Depth & 0.73 & 2 \\
\hline \multirow{2}{*}{ Natural } & Core Distance & 0.25 & 2 \\
Shoreline & Date Collected & 0.04 & 2 \\
& Core Depth & 0.75 & 2 \\
\hline
\end{tabular}


Table S2c. One-way ANOVA of sediment C:N ratio collected during May, August and October 2015. Significant $\mathrm{p}$-values indicated in bold $(\mathrm{df}=$ degrees of freedom).

\begin{tabular}{|clcc|}
\hline \multirow{4}{*}{ Eroded } & p-value & df \\
\cline { 3 - 4 } Shoreline & Core Distance & $<\mathbf{0 . 0 5}$ & 2 \\
& Date Collected & 0.20 & 2 \\
& Core Depth & $\mathbf{0 . 0 2}$ & 2 \\
\hline \multirow{2}{*}{ Hardened } & Core Distance & 0.99 & 2 \\
Shoreline & Date Collected & 0.97 & 2 \\
& Core Depth & 0.98 & 2 \\
\hline \multirow{2}{*}{ Living } & Core Distance & 0.44 & 2 \\
Shoreline & Date Collected & 0.08 & 2 \\
& Core Depth & 0.15 & 2 \\
\hline \multirow{2}{*}{ Natural } & Core Distance & $<\mathbf{0 . 0 5}$ & 2 \\
Shoreline & Date Collected & $<\mathbf{0 . 0 5}$ & 2 \\
& Core Depth & $\mathbf{0 . 0 1}$ & 2 \\
\hline
\end{tabular}


Table S4. Mean percent clay, silt and sand ( \pm SD) at each site treatment type by depth and date collected.

\begin{tabular}{|c|c|c|c|c|c|c|c|c|c|c|c|c|c|}
\hline \multicolumn{5}{|c|}{ Eroded Shoreline } & \multicolumn{3}{|c|}{ Hardened Shoreline } & \multicolumn{3}{|c|}{ Living Shoreline } & \multicolumn{3}{|c|}{ Natural Shoreline } \\
\hline Date & $\begin{array}{c}\text { Core } \\
\text { Depth } \\
\text { (cm) }\end{array}$ & $\begin{array}{c}\% \\
\text { Clay }\end{array}$ & $\%$ Silt & $\begin{array}{c}\% \\
\text { Sand }\end{array}$ & $\%$ Clay & $\%$ Silt & $\%$ Sand & $\%$ Clay & $\%$ Silt & $\%$ Sand & \% Clay & $\%$ Silt & $\%$ Sand \\
\hline \multirow[t]{5}{*}{ Spring } & $0-1$ & $\begin{array}{c}0.34 \\
(0.05)\end{array}$ & $\begin{array}{l}16.84 \\
(1.82)\end{array}$ & $\begin{array}{l}84.82 \\
(1.91)\end{array}$ & $\begin{array}{c}0.19 \\
(0.04)\end{array}$ & $\begin{array}{l}10.70 \\
(1.65)\end{array}$ & $\begin{array}{l}89.10 \\
(1.69)\end{array}$ & $\begin{array}{c}0.07 \\
(0.03)\end{array}$ & $\begin{array}{c}6.20 \\
(1.69)\end{array}$ & $\begin{array}{l}93.73 \\
(1.73)\end{array}$ & $\begin{array}{c}0.53 \\
(0.15)\end{array}$ & $\begin{array}{l}23.53 \\
(6.60)\end{array}$ & $\begin{array}{l}75.95 \\
(6.75)\end{array}$ \\
\hline & $1-2$ & $\begin{array}{c}0.47 \\
(0.04)\end{array}$ & $\begin{array}{l}20.53 \\
(1.54)\end{array}$ & $\begin{array}{l}80.91 \\
(2.00)\end{array}$ & $\begin{array}{c}0.18 \\
(0.04)\end{array}$ & $\begin{array}{l}10.24 \\
(1.90)\end{array}$ & $\begin{array}{l}89.57 \\
(1.94)\end{array}$ & $\begin{array}{c}0.07 \\
(0.03)\end{array}$ & $\begin{array}{c}6.75 \\
(1.27)\end{array}$ & $\begin{array}{l}93.56 \\
(1.31)\end{array}$ & $\begin{array}{c}0.64 \\
(0.19)\end{array}$ & $\begin{array}{l}24.77 \\
(6.58)\end{array}$ & $\begin{array}{l}74.59 \\
(6.76)\end{array}$ \\
\hline & $2-3$ & $\begin{array}{c}0.34 \\
(0.04)\end{array}$ & $\begin{array}{l}15.75 \\
(1.40)\end{array}$ & $\begin{array}{l}86.83 \\
(2.07)\end{array}$ & $\begin{array}{c}0.34 \\
(0.05)\end{array}$ & $\begin{array}{l}13.64 \\
(1.89)\end{array}$ & $\begin{array}{l}86.03 \\
(1.94)\end{array}$ & $\begin{array}{c}0.04 \\
(0.02)\end{array}$ & $\begin{array}{c}4.90 \\
(0.80)\end{array}$ & $\begin{array}{l}95.06 \\
(0.81)\end{array}$ & $\begin{array}{c}0.73 \\
(0.22)\end{array}$ & $\begin{array}{l}24.68 \\
(6.98)\end{array}$ & $\begin{array}{l}74.59 \\
(7.19)\end{array}$ \\
\hline & $3-4$ & $\begin{array}{c}0.34 \\
(0.06)\end{array}$ & $\begin{array}{l}14.24 \\
(1.90)\end{array}$ & $\begin{array}{l}86.28 \\
(2.40)\end{array}$ & $\begin{array}{c}0.68 \\
(0.12)\end{array}$ & $\begin{array}{l}24.15 \\
(3.77)\end{array}$ & $\begin{array}{c}75.18 \\
(3.88)\end{array}$ & $\begin{array}{c}0.02 \\
(0.01)\end{array}$ & $\begin{array}{c}3.90 \\
(0.56)\end{array}$ & $\begin{array}{l}96.08 \\
(0.57)\end{array}$ & $\begin{array}{c}0.65 \\
(0.20)\end{array}$ & $\begin{array}{l}20.58 \\
(5.89)\end{array}$ & $\begin{array}{l}78.77 \\
(6.08)\end{array}$ \\
\hline & $4-5$ & $\begin{array}{c}0.40 \\
(0.04)\end{array}$ & $\begin{array}{l}15.94 \\
(1.25)\end{array}$ & $\begin{array}{l}83.61 \\
(1.30)\end{array}$ & $\begin{array}{c}0.44 \\
(0.08)\end{array}$ & $\begin{array}{l}17.32 \\
(2.78)\end{array}$ & $\begin{array}{l}76.69 \\
(2.59)\end{array}$ & $\begin{array}{c}0.01 \\
(0.00)\end{array}$ & $\begin{array}{c}3.12 \\
(0.53)\end{array}$ & $\begin{array}{l}96.86 \\
(0.53)\end{array}$ & $\begin{array}{c}0.77 \\
(0.23)\end{array}$ & $\begin{array}{l}25.24 \\
(7.52)\end{array}$ & $\begin{array}{r}73.99 \\
(7.74)\end{array}$ \\
\hline \multirow[t]{5}{*}{ Fall } & $0-1$ & $\begin{array}{c}0.50 \\
(0.07)\end{array}$ & $\begin{array}{l}20.95 \\
(2.21)\end{array}$ & $\begin{array}{l}78.56 \\
(2.28)\end{array}$ & $\begin{array}{c}1.31 \\
(0.28)\end{array}$ & $\begin{array}{l}34.67 \\
(5.67)\end{array}$ & $\begin{array}{l}66.66 \\
(5.04)\end{array}$ & $\begin{array}{c}0.13 \\
(0.04)\end{array}$ & $\begin{array}{c}7.55 \\
(1.01)\end{array}$ & $\begin{array}{l}95.11 \\
(1.35)\end{array}$ & $\begin{array}{c}0.64 \\
(0.19)\end{array}$ & $\begin{array}{l}25.89 \\
(6.63)\end{array}$ & $\begin{array}{c}73.47 \\
(6.82)\end{array}$ \\
\hline & $1-2$ & $\begin{array}{c}0.60 \\
(0.08)\end{array}$ & $\begin{array}{l}24.38 \\
(2.48)\end{array}$ & $\begin{array}{c}75.03 \\
(2.56)\end{array}$ & $\begin{array}{c}0.45 \\
(0.11)\end{array}$ & $\begin{array}{l}15.90 \\
(3.53)\end{array}$ & $\begin{array}{l}83.65 \\
(3.63)\end{array}$ & $\begin{array}{c}0.03 \\
(0.01)\end{array}$ & $\begin{array}{c}5.80 \\
(0.21)\end{array}$ & $\begin{array}{l}94.17 \\
(0.11)\end{array}$ & $\begin{array}{c}0.79 \\
(0.24)\end{array}$ & $\begin{array}{l}27.65 \\
(7.76)\end{array}$ & $\begin{array}{l}71.56 \\
(8.00)\end{array}$ \\
\hline & $2-3$ & $\begin{array}{c}0.59 \\
(0.08)\end{array}$ & $\begin{array}{l}21.58 \\
(2.49)\end{array}$ & $\begin{array}{c}77.83 \\
(2.57)\end{array}$ & $\begin{array}{c}0.39 \\
(0.08)\end{array}$ & $\begin{array}{l}13.35 \\
(2.42)\end{array}$ & $\begin{array}{l}86.26 \\
(2.50)\end{array}$ & $\begin{array}{c}0.06 \\
(0.02)\end{array}$ & $\begin{array}{c}6.61 \\
(0.74)\end{array}$ & $\begin{array}{l}93.33 \\
(1.82)\end{array}$ & $\begin{array}{c}0.64 \\
(0.19)\end{array}$ & $\begin{array}{l}22.07 \\
(6.19)\end{array}$ & $\begin{array}{l}77.29 \\
(6.38)\end{array}$ \\
\hline & $3-4$ & $\begin{array}{c}0.59 \\
(0.07)\end{array}$ & $\begin{array}{l}22.82 \\
(2.44)\end{array}$ & $\begin{array}{c}76.60 \\
(2.52)\end{array}$ & $\begin{array}{c}0.29 \\
(0.07)\end{array}$ & $\begin{array}{l}10.64 \\
(2.16)\end{array}$ & $\begin{array}{l}89.07 \\
(2.23)\end{array}$ & $\begin{array}{c}0.03 \\
(0.01)\end{array}$ & $\begin{array}{c}6.37 \\
(0.26)\end{array}$ & $\begin{array}{l}93.59 \\
(0.00)\end{array}$ & $\begin{array}{c}0.84 \\
(0.24)\end{array}$ & $\begin{array}{l}26.77 \\
(7.56)\end{array}$ & $\begin{array}{l}72.39 \\
(7.80)\end{array}$ \\
\hline & $4-5$ & $\begin{array}{c}0.45 \\
(0.07)\end{array}$ & $\begin{array}{l}18.99 \\
(2.08)\end{array}$ & $\begin{array}{l}81.35 \\
(2.15)\end{array}$ & $\begin{array}{c}0.17 \\
(0.04)\end{array}$ & $\begin{array}{c}7.12 \\
(1.03)\end{array}$ & $\begin{array}{l}92.71 \\
(1.07)\end{array}$ & $\begin{array}{c}0.03 \\
(0.01)\end{array}$ & $\begin{array}{c}5.55 \\
(0.38)\end{array}$ & $\begin{array}{l}94.41 \\
(0.18)\end{array}$ & $\begin{array}{c}0.93 \\
(0.30)\end{array}$ & $\begin{array}{l}25.45 \\
(8.03)\end{array}$ & $\begin{array}{c}73.63 \\
(8.32)\end{array}$ \\
\hline
\end{tabular}


Table S5. Mean percent nitrogen $(\mathrm{N})$, carbon $(\mathrm{C})$, and $\mathrm{C}: \mathrm{N}$ ratio $( \pm \mathrm{SD})$ at each site treatment type by depth and date collected.

\begin{tabular}{|c|c|c|c|c|c|c|c|c|c|c|c|c|c|}
\hline \multicolumn{2}{|c|}{ Site Treatment } & \multicolumn{3}{|c|}{ Eroded Shoreline } & \multicolumn{3}{|c|}{ Hardened Shoreline } & \multicolumn{3}{|c|}{ Living Shoreline } & \multicolumn{3}{|c|}{ Natural Shorline } \\
\hline Date & $\begin{array}{l}\text { Core Depth } \\
\text { (cm) }\end{array}$ & $\% \mathrm{~N}$ & $\% \mathrm{C}$ & C:N & $\% \mathrm{~N}$ & $\% \mathrm{C}$ & C:N & $\% \mathrm{~N}$ & $\% \mathrm{C}$ & C:N & $\% \mathrm{~N}$ & $\% \mathrm{C}$ & $\mathrm{C}: \mathrm{N}$ \\
\hline May & $0-1$ & $0.24(0.01)$ & $2.67(0.09)$ & $12.81(0.19)$ & $0.17(0.01)$ & $1.97(0.07)$ & $10.25(0.37)$ & $0.08(0.00)$ & $1.08(0.06)$ & $7.78(0.49)$ & $0.24(0.02)$ & $2.71(0.18)$ & $7.95(0.50)$ \\
\hline May & $1-2$ & $0.21(0.01)$ & $2.57(0.09)$ & $15.12(0.25)$ & $0.16(0.01)$ & $1.52(0.06)$ & $8.43(0.36)$ & $0.21(0.03)$ & $0.98(0.04)$ & $7.32(0.47)$ & $0.20(0.02)$ & $2.15(0.15)$ & $8.47(0.48)$ \\
\hline May & $2-3$ & $0.21(0.01)$ & $3.12(0.17)$ & $16.36(0.24)$ & $0.12(0.00)$ & $1.47(0.04)$ & $11.36(0.37)$ & $0.11(0.00)$ & $0.98(0.04)$ & $9.58(0.36)$ & $0.20(0.02)$ & $2.50(0.15)$ & $10.05(0.54)$ \\
\hline May & $3-4$ & $0.23(0.01)$ & $3.53(0.26)$ & $15.38(0.28)$ & $0.11(0.00)$ & $1.31(0.04)$ & $9.51(0.37)$ & $0.10(0.01)$ & $0.88(0.03)$ & $8.22(0.42)$ & $0.22(0.02)$ & $2.84(0.21)$ & $9.03(0.60)$ \\
\hline May & $4-5$ & $0.24(0.01)$ & $3.92(0.31)$ & $16.25(0.27)$ & $0.08(0.00)$ & $1.16(0.04)$ & $9.37(0.40)$ & $0.07(0.00)$ & $0.83(0.03)$ & $7.10(0.50)$ & $0.28(0.03)$ & $3.83(0.47)$ & $9.16(0.60)$ \\
\hline Aug & $0-1$ & $0.26(0.01)$ & $2.94(0.13)$ & $13.38(0.17)$ & $0.09(0.01)$ & $1.18(0.12)$ & $8.89(1.27)$ & $0.14(0.02)$ & $1.78(0.18)$ & $8.62(0.59)$ & $0.96(0.14)$ & $2.87(0.15)$ & $9.12(0.60)$ \\
\hline Aug & $1-2$ & $0.24(0.01)$ & $2.83(0.14)$ & $11.66(0.19)$ & $0.12(0.01)$ & $1.17(0.04)$ & $9.28(0.61)$ & $0.27(0.05)$ & $1.33(0.09)$ & $7.56(0.49)$ & $0.48(0.08)$ & $2.66(0.16)$ & $12.52(0.87)$ \\
\hline Aug & $2-3$ & $0.22(0.01)$ & $2.73(0.12)$ & $13.75(0.22)$ & $0.10(0.01)$ & $1.18(0.06)$ & $8.68(0.47)$ & $0.17(0.02)$ & $1.60(0.17)$ & $7.64(0.46)$ & $0.77(0.11)$ & $2.42(0.17)$ & $7.54(0.55)$ \\
\hline Aug & $3-4$ & $0.19(0.01)$ & $2.87(0.13)$ & $17.67(0.53)$ & $0.11(0.01)$ & $1.39(0.07)$ & $9.86(0.39)$ & $0.18(0.03)$ & $0.98(0.06)$ & $6.19(0.48)$ & $0.72(0.10)$ & $3.20(0.24)$ & $8.88(0.50)$ \\
\hline Aug & $4-5$ & $0.18(0.01)$ & $2.33(0.08)$ & $15.16(0.22)$ & $0.09(0.00)$ & $1.29(0.04)$ & $10.77(0.48)$ & $0.08(0.01)$ & $1.36(0.14)$ & $6.78(0.63)$ & $0.48(0.07)$ & $3.53(0.32)$ & $8.22(0.60)$ \\
\hline Oct & $0-1$ & $0.29(0.03)$ & $1.78(0.05)$ & $11.98(0.25)$ & $0.44(0.03)$ & $5.96(0.38)$ & $12.34(0.55)$ & $0.16(0.01)$ & $2.53(0.21)$ & $15.33(0.90)$ & $0.24(0.02)$ & $2.90(0.19)$ & $12.90(0.58)$ \\
\hline Oct & $1-2$ & $0.38(0.04)$ & $1.74(0.04)$ & $13.31(0.28)$ & $0.43(0.03)$ & $5.32(0.34)$ & $12.68(0.57)$ & $0.16(0.01)$ & $2.17(0.19)$ & $12.10(0.61)$ & $0.24(0.02)$ & $3.31(0.28)$ & $13.13(0.68)$ \\
\hline Oct & $2-3$ & $0.14(0.01)$ & $1.83(0.08)$ & $15.35(0.27)$ & $0.39(0.02)$ & $5.31(0.35)$ & $11.92(0.51)$ & $0.16(0.02)$ & $2.24(0.24)$ & $8.59(0.59)$ & $0.28(0.03)$ & $4.08(0.51)$ & $11.58(0.61)$ \\
\hline Oct & $3-4$ & $0.26(0.03)$ & $2.01(0.12)$ & $13.98(0.27)$ & $0.45(0.03)$ & $6.83(0.38)$ & $11.64(0.49)$ & $0.10(0.01)$ & $1.33(0.12)$ & $8.05(0.58)$ & $0.30(0.03)$ & $2.60(0.16)$ & $11.21(0.61)$ \\
\hline Oct & $4-5$ & $0.31(0.04)$ & $2.02(0.12)$ & $14.17(0.24)$ & $0.63(0.05)$ & $7.12(0.41)$ & $11.76(0.45)$ & $0.05(0.01)$ & $1.00(0.08)$ & $6.47(0.73)$ & $0.29(0.03)$ & $2.53(0.17)$ & $12.37(0.72)$ \\
\hline
\end{tabular}


Table S6. Species collected at each treatment site in the Narrow River, RI in 2015 with their mean abundance $( \pm$ SD) and functional feeding groups

Filter feeder (FF), deposit feeder (DF), scavenger (SC), omnivore (OMNI), carnivore (CARN), herbivore (HERB).

\begin{tabular}{|c|c|c|c|c|c|}
\hline \multirow{2}{*}{ Species } & \multirow{2}{*}{$\begin{array}{l}\text { Functional } \\
\text { Group }\end{array}$} & \multicolumn{4}{|c|}{ Abundance per treatment type } \\
\hline & & \multicolumn{2}{|l|}{ ES } & LS & \multirow[t]{2}{*}{ NS } \\
\hline $\begin{array}{l}\text { Phylum } \\
\text { Mollusca }\end{array}$ & & & & & \\
\hline Abra aequalis & $\mathrm{FF}$ & & 2 & & \\
\hline Ameritella agilis & $\mathrm{DF}$ & 1 & 1 & 1 & \\
\hline $\begin{array}{l}\text { Crepidula } \\
\text { convexa }\end{array}$ & $\mathrm{FF}$ & & 1 & & \\
\hline Ecrobia truncata & $\mathrm{DF}$ & $2.5(2.71)$ & $1.5(0.71)$ & 1 & $1.89(1.17)$ \\
\hline Gemma gemma & $\mathrm{FF}$ & $15.87(20.5)$ & $\begin{array}{l}13.29 \\
(13.82)\end{array}$ & $6(9.69)$ & $\begin{array}{l}18.85 \\
(24.69)\end{array}$ \\
\hline $\begin{array}{l}\text { Geukensia } \\
\text { demissa }\end{array}$ & FF/DF & 1 & & & \\
\hline Lacuna vincta & DF & 1 & 1 & & \\
\hline $\begin{array}{l}\text { Mercenaria } \\
\text { mercenaria }\end{array}$ & $\mathrm{FF}$ & & 1 & & \\
\hline Mytilus edulis & $\mathrm{FF}$ & 1 & 2 & $\begin{array}{l}3.6 \\
(4.77)\end{array}$ & \\
\hline Solemya velum & $\begin{array}{l}\text { FF and } \\
\text { chemoautotroph }\end{array}$ & & 1 & & 1 \\
\hline Tritia obsoleta & $\mathrm{DF}$ & 1 & 6 & & 1 \\
\hline Tritia trivittata & SC & & 1 & & \\
\hline $\begin{array}{l}\text { Phylum } \\
\text { Annelida }\end{array}$ & & & & & \\
\hline Alitta succinea & OMNI & $2.76(2.12)$ & $2.12(1.45)$ & $\begin{array}{l}1.3 \\
(0.67)\end{array}$ & $1.4(0.89)$ \\
\hline $\begin{array}{l}\text { Amphitrite } \\
\text { ornata }\end{array}$ & $\mathrm{DF}$ & & 1 & & \\
\hline
\end{tabular}




\begin{tabular}{|c|c|c|c|c|c|}
\hline Aricidea spp. & $\mathrm{DF}$ & 1 & & & \\
\hline $\begin{array}{l}\text { Capitella } \\
\text { capitata }\end{array}$ & $\mathrm{DF}$ & $2.45(1.81)$ & $4.8(5.98)$ & $2(1.26)$ & \\
\hline $\begin{array}{l}\text { Clymenella } \\
\text { torquata }\end{array}$ & CARN & 2 & $2.29(1.89)$ & 3 & 1 \\
\hline $\begin{array}{l}\text { Drilonereis } \\
\text { longa }\end{array}$ & CARN & $5(3.61)$ & & & \\
\hline $\begin{array}{l}\text { Eumida } \\
\text { sanguinea }\end{array}$ & CARN & & 1 & & \\
\hline $\begin{array}{l}\text { Eusyllis } \\
\text { lamelligera }\end{array}$ & OMNI & & 1 & & \\
\hline Exogone sp & CARN & $2(1.41)$ & $3.55(4.61)$ & & 1 \\
\hline $\begin{array}{l}\text { Glycera } \\
\text { americana }\end{array}$ & $\mathrm{DF}$ & . & & & \\
\hline $\begin{array}{l}\text { Hypereteone } \\
\text { heteropoda }\end{array}$ & CARN & $2.8(2.49)$ & $1.6(0.89)$ & $\begin{array}{l}4.67 \\
(5.51)\end{array}$ & $2(1.73)$ \\
\hline $\begin{array}{l}\text { Leitoscoloplos } \\
\text { fragilis }\end{array}$ & DF & $1.4(0.89)$ & $5.04(6.47)$ & $\begin{array}{l}4.2 \\
(3.17)\end{array}$ & $5.22(4.47)$ \\
\hline $\begin{array}{l}\text { Levinsenia } \\
\text { gracilis }\end{array}$ & DF & & $1.8(1.30)$ & $\begin{array}{l}7.67 \\
(10.69)\end{array}$ & 1 \\
\hline $\begin{array}{l}\text { Marenzelleria } \\
\text { viridis }\end{array}$ & $\mathrm{DF}$ & 1 & $3.44(3.32)$ & $\begin{array}{l}1.33 \\
(0.58)\end{array}$ & 1 \\
\hline Micrura leidyi & & & & & 1 \\
\hline Nephtys caeca & CARN/ DF & & 1 & & \\
\hline Oligochaeta & DF & 1 & & & \\
\hline $\begin{array}{l}\text { Owenia } \\
\text { fusiformis }\end{array}$ & $\mathrm{DF}$ & 1 & 3 & & \\
\hline $\begin{array}{l}\text { Pectinaria } \\
\text { gouldii }\end{array}$ & DF & & $1.5(0.71)$ & & \\
\hline $\begin{array}{l}\text { Phyllodoce } \\
\text { groenlandica }\end{array}$ & CARN/ DF & & 2 & & \\
\hline Polydora cornuta & CARN & 1 & $1.67(1.21)$ & $\begin{array}{l}2.33 \\
(2.31)\end{array}$ & $2(1.41)$ \\
\hline Prionspio sp & $\mathrm{DF}$ & 2 & & & \\
\hline
\end{tabular}




\begin{tabular}{|c|c|c|c|c|c|}
\hline Pygospio elegans & DF & & 2 & & \\
\hline $\begin{array}{l}\text { Scalibregma } \\
\text { inflatum }\end{array}$ & $\mathrm{DF}$ & 1 & & & \\
\hline $\begin{array}{l}\text { Scoletoma } \\
\text { fragilis }\end{array}$ & OMNI & & $3.5(3.54)$ & & \\
\hline Scoletoma tenuis & CARN & $3.86(2.98)$ & $5.2(5.59)$ & $\begin{array}{l}2.86 \\
(2.84)\end{array}$ & $4.5(6.93)$ \\
\hline $\begin{array}{l}\text { Streblospio } \\
\text { henedicti }\end{array}$ & FF/DF & $1.5(0.71)$ & $2.67(2.08)$ & & 1 \\
\hline Syllidae & OMNI & & 1 & & \\
\hline Tharyx acutus & DF & 1 & $1.67(1.15)$ & $\begin{array}{l}4.2 \\
(3.27)\end{array}$ & $3.5(2.12)$ \\
\hline $\begin{array}{l}\text { Phylum } \\
\text { Arthropoda }\end{array}$ & & & & & \\
\hline Ampelisca abdita & DF & $\begin{array}{l}10.07 \\
(11.29)\end{array}$ & $\begin{array}{l}11.38 \\
(15.04)\end{array}$ & $\begin{array}{l}3.67 \\
(2.52)\end{array}$ & \\
\hline Asterope mariae & OMNI/SC & $14.9(17.82)$ & $9.5(10.37)$ & & 5 \\
\hline $\begin{array}{l}\text { Apocorophium } \\
\text { lacustre }\end{array}$ & DF & $6.67(3.20)$ & $3.29(2.43)$ & & \\
\hline $\begin{array}{l}\text { Chondroche } \\
\text { savignyi }\end{array}$ & $\mathrm{DF}$ & & 1 & & \\
\hline Copepod & HERB & 1 & & & \\
\hline Edotia triloba & $\mathrm{DF}$ & $1.75(1.5)$ & $1.5(1.22)$ & & 1 \\
\hline $\begin{array}{l}\text { Eurypanopeus } \\
\text { depressus }\end{array}$ & OMNI & & 1 & & \\
\hline $\begin{array}{l}\text { Gammarus } \\
\text { mucronatus }\end{array}$ & $\mathrm{DF}$ & $6(7.81)$ & & 1 & 1 \\
\hline Lysianopsis Alba & DF & $6(4.24)$ & $5.78(9.93)$ & & \\
\hline $\begin{array}{l}\text { Microdeutopus } \\
\text { gryllotalpa }\end{array}$ & HERB & $7.57(8.78)$ & $8.09(6.3)$ & & 1 \\
\hline $\begin{array}{l}\text { Panopeus } \\
\text { herbstii }\end{array}$ & CARN & & 1 & & \\
\hline $\begin{array}{l}\text { Psammonyx } \\
\text { nobilis }\end{array}$ & OMNI & & 1 & & \\
\hline
\end{tabular}




\begin{tabular}{|l|l|l|l|l|}
$\begin{array}{l}\text { Pseudoleptocuma } \\
\text { minor }\end{array}$ & HERB/DF & 1 & $2.6(3.05)$ & \\
$\begin{array}{l}\text { Echinodermata } \\
\text { Sclerodactyla } \\
\text { briareus } \\
\text { Nematode }\end{array}$ & FF/DF & 1 & & \\
$\begin{array}{l}\text { Nematode } \\
\text { DF }\end{array}$ & 121 & $\begin{array}{l}19.86 \\
(22.26)\end{array}$ & $\begin{array}{l}8.5 \\
(3.54)\end{array}$ & 12 \\
\hline
\end{tabular}




\section{References Cited}

Barbier ED, Georgiou IY, Enchelmeyer B, Reed DJ (2013). The value of wetlands in protecting southeast Louisiana from hurricane storm surges. PLoS ONE 8(3): e58715. doi: 10.1371/journal.pone.0058715.

Bates D, MM, B Bolker, S Walker S. (2014). lme4: Linear mixed-effects models using Eigen and S4. ArXiv e-print; submitted to _Journal of Statistical Software_. Retrieved from http://arxiv.org/abs/1406.5823>

Bertness, MD, PJ Ewanchuk, BR Silliman. (2002). Anthropogenic modification of New England salt marsh landscapes. Ecology, 99(3), 1395-1398.

Bilkovic, DM, MM Rogerro, CH Hershner, and KH Havens. (2006). Influence of land use on macrobenthic communities in nearshore estuarine habitats. Estuaries and Coasts, 29(6B), 1185-1195.

Bilkovic, DM and MM Roggero. (2008). Effects of coastal development on nearshore estuarine nekton communities. Marine Ecology Progress Series, 358, 27-39. doi: $10.3354 / \mathrm{meps} 07279$

Bilkovic, DM and MM Mitchell. (2013). Ecological tradeoffs of stabilized salt marshes as a shoreline protection strategy: effects of artificial structures on macrobenthic assemblages. Ecological Engineering, 61, 469-481.

Currin, CA, W Chappell, and A Deaton. (2010). Developing alternative shoreline armoring strategies: The living shoreline approach in North Carolina. Scientific Investigations Report.

Chang, S, F Steimle, R Reid, S Fromm, S Zdanowicz, and R Pikanowski. (1992). Association of benthic macrofauna with habitat types and quality in the New York Bight. Marine Ecology Progress Series, 89, 237-251.

Craft, C and J Sacco. (2003). Long-term succession of benthic infauna communitieson constructed Spartina alterniflora marshes. Marine Ecology Progress Series, 257, 45-58.

CRMC, R. (2015). The Rhode Island Sea Level Affecting Marshes Model (SLAMM) Project (January 2015 ed.).

Deegan, LA, DS Johnson, RS Warren, BJ Peterson, JW Fleeger, S Fagherazzi, and WM Wollheim. (2012). Coastal eutrophication as a driver of salt marsh loss. Nature, 490, 388-394. doi:doi: 10.1038/nature11533

Dugan, JE, DM Hubbard, IF Rodil, DL Revell, and S Schroeter. (2008). Ecological effects of coastal armoring on sandy beaches. Marine Ecology, 29(s1), 160170. doi:10.1111/j.1439-0485.2008.00231.x

EPA. (2002). Standard Operating Procedure for Benthic Invertebrate Field Sampling Procedure. EPA.

EPA. (2005). Standard Operating Procedure For Analysis of Total Organic Carbon in Sediments (Dry Combustion, IR Detection).

Gillett, DJ and LC Schaffner. (2009). Benthos of the York River. Journal of Coastal Research(57), 80-89.

Gittman, RK, CH Peterson, CA Currin, FJ Fodrie, MF Piehler, JF Bruno. (2016). Living shorelines can enhance the nursery role of threatened estuarine habitats. Ecological Applications, 26(1), 249-263. 
Gittman, RK, FJ Fodrie, AM Popowich, DA Keller, JF Bruno, CA Currin, CH Peterson, and MF Piehler. (2015). Engineering away our natural defenses: an analysis of shoreline hardening in the US. Frontiers in Ecology and the Environment, 13(6), 301-307.

Hyland, J L Balthis, I Karakassis, P Magni, A Petrov, J Shine, O Vestergaard, and R Warwick. (2005). Organic carbon contenct of sediments as an indicator of stress in the marine benthos. Marine Ecology Progress Series, 295, 91-103.

Lawless, AS and RE Seitz. (2014). Effects of shoreline stabilization and environmental variables on benthic infaunal communitites in the Lynnhaven River System of Chesapeake Bay. Journal of Experimental Marine Biology and Ecology, 457, 41-50.

Minello, TJ, KW Able, MP Weinstein, and CG Hays. (2003). Salt marshes as nurseries for nekton: testing hypotheses on density, growth and survival through meta-analysis. Marine Ecology Progress Series, 246, 39-59.

Mitchell, B. (2013). Ecological traeoffs of stabilized salt marshes as a shoreline protection strategy: Effects of artificial structures on macrobenthic assemblages. Ecological Engineering, 61, 469-481.

Mulkana, MS. (1966). The growth and feeding habits of juvenile fishes in two rhode island estuaries. Gulf Research Reports, 2(2), 97-167.

Neckles, HA, GR Guntenspergen, WG Shriver, NP Danz, WA Wiest, JL Nagel, and JH Olker. (2013). Identification of Metrics to Monitor Salt Marsh Integrity on National Wildlife Refuges In Relation to Conservation and Management Objectives. Retrieved from U.S. Fish and Wildlife Service, Northeast Region:

Neira, C, ED Grosholz, LA Levin, and R Blake. (2006). Mechanisms Generating Modification of Benthos Following Tidal Flat Invasion by a Spartina Hybrid. Ecological Society of America, 16(4), 1391-1404.

NOAA. (2016). General Coastline and Shorline Mileage of the United States.

Nordstrom, KF, NL Jackson, P Rafferty, NA Taineault, and Grafals-Soto. (2009). Effects of bulkheads on estuarine shores: an examples from Fire Island National Seashore, USA. Journal of Coastal Research, 156, 18-192.

Nordström, MC, CA Currin, TS Talley, CR Whitcraft, and LA Levin. (2014). Benthic food-web succession in a developing salt marsh. Marine Ecology Progress Series, 500, 43-55.

O'Connell, JF (2010). Shoreline armoring impacts and management along the shores of Massachusetts and Kauai, Hawaii. U.S.G.S. Scientific Investigations Report (5254), 65-76.

Olsen, YS, SE Fox, L Hofmann, and I Valiela. (2013). Benthic community composition and faunal stable isotopic signatures differ across small spatial scales in a temperate estuary. Marine Environmental Research, 86, 12-20.

Patricio, J, JM Neto, H Teixeira, F Salas, and JC Marques. (2009). The robustness of ecological indicators to detect long-term changes in the macrobenthos of estuarine systems. Mairine Environmental Research, 68(1), 25-36. doi:10.1016/j.marenvres.2009.04.001

Pelletier, MC, AJ Gold, JF Heltshe, and HW Buffum. (2010). A method to identify estuarine macroinvertebrate pollution indicator species in the Virginian 
Biogeographic Province. Ecological Indicators, 10(5), 1037-1048. doi:10.1016/j.ecolind.2010.03.005

Pennings, SC, and MD Bertness. (2001). Salt marsh communities. Marine community ecology, 289-316.

Pollock, LA. practical guide to the marine animals of Northeastern North America. New Brunswick: Rutgers University Press. 1998.

RAE, (Restore America's Estuaries). (2015). Living Shorelines: From barriers to opportunitites. Arlington, VA. Retrieved from www.estuaries.org

Sarda, R., K Foreman, and I Valiela. (1995). Macroinfauna of a southern new england salt marsh: seasonal dynamics and production. Marine Biology, 121, 431-445.

Savage, C., SF Thrush, AM Lohrer, and JE Hewitt. (2012). Ecosystem services transcend boundaries: estuaries provide resource subsidies and influence functional diversity in coastal benthic communities. PLoS One, 7(8), e42708. doi:10.1371/journal.pone.0042708

Save The Bay (2013). Coastal Erosion and Adaptation on the Rhode Island Coastline. Retrieved from Save the Bay, Narragansett Bay: www.savebay.org

Seitz, RD, RN Lipcius, NH Olmstead, MS Seebo, and DM Lambert. (2006). Influence of shallow-water habitats and shoreline development on abundance, biomass, and diversity of benthic prey and predators in Chesapeake Bay. Marine Ecology Progress Series, 326, 11-27.

Scyphers, SB, SP Powers, KL Heck, and D Byron. (2011). Oyster reefs as natural breakwaters mitigate shoreline loss and facilitate fisheries. PLoS One, 6(8), e22396. doi:10.1371/journal.pone.0022396

Shepard, C, C Crain, and M Beck. (2011). The protective role of Coastal Marshes: A systematic Review and Meta-analysis. PLoS One, 6(11). doi:doi:10.1371/journal.pone.0027374

Sutton-Grier, AE, K Wowk, and H Bamford. (2015). Future of our coasts: The potential for natural and hybrid infrastructure to enhance the resilience of our coastal communitites, economics, and ecosystems. Environmental Science \& Policy, 51, 137-148.

Swann, L. (2008). The Use of Living Shorelines to Mitigate the Effects of Storm Events on Daughin Island, Alabama, USA. American Fisheries Society Symposium, 64.

Team, R. C. (2014). R: A language and environment for statistical computing: R Foundation for Statistical Computing, Vienna, Austria. Retrieved from URL http://www.R-project.org/

Thistle, D. (1981). Natural physical disturbances and communitites of marine soft bottoms. Marine Ecology Progress Series, 6, 223-228.

USFW (U.S. Fish and Wildlife Services). (2014). Environmental Assessment: Narrow River Estuary Resiliency Restoration Program. Retrieved from USFW:

Weisberg, JF a. S. (2011). An \{R\} Companion to Applied Regression: Sage, Thousand Oaks CA. Retrieved from http://socserv.socsci.mcmaster.ca/jfox/Books/Companion

Weiss, HM. (1995) Marine animals of Southern New England and New York: identification to 
common nearshore and shallow water macrofauna. Hartford, CT, State

Geological and

Natural History Survey of Connecticut Department of Environmental

Protection.

Widdicombe, S. and AC Melanie (2001). The interaction between physical

disturbance and

organic enrichment: An important element in structuring benthic communities.

Limnology and Oceanography, 7, doi: 10.4319/lo.2001.46.7.1720.

Wenger, SJ and MC Freeman (2008). Estimating Species Occurrence, Abundance, and

Detection Probability Using Zero-Inflated Distributions. Ecology. 89(10), 2953-2959.

Wickham, H. (2009). ggplot2: elegant graphics for data analysis: Spinger New York. Retrieved from http://had.co.nz/ggplot2/book

Wildish, DJ and DD Kristmanson. (1979). Tidal energy and sublittoral macrobenthic animals in estuaries. Journal of the Fisheries Board of Canada, 36(10), 11971206.

Yang, SL, H Li, T Ysebaert, TJ Bouma, WX Zhang, YY Wang, P Li, M Li and X Ding. (2008). Spatial and temporal variations in sediment grain size in tidal wetlands, Yangtze Delta: On the role of physical and biotic controls. Estuarine, Coastal and Shelf Science, 77(4), 657-671.

Yepsen, M, Moody, J Schuster, E editors (2016). A Framework for developing monitoring plans for coastal wetland restoration and living shoreline projects in New Jersey. A report prepared by the New Jersey Measure and Monitoring Workgroup of the NH Resilient Coastlines Initiative, with support form the NOAA National Oceanic and Atmopheric Administration (NOAA) Coastal Resilience (CRest) Grant program (NA14N)S4830006).

Zimmerman, AR and R Benner (1994). Denitrification, nutrient regeneration and carbon mineralization in sediments of Galveston Bay, Texas, USA. Marine Ecology Progress Series. 114, 275-288. 